\section{Physiochemical and Sensory Attributes of Fresh Blackberries Grown in the Southeastern United States}

\author{
Renee T. Threlfall ${ }^{1}$ \\ Institute of Food Science and Engineering, University of Arkansas, 2650 \\ North Young Avenue, Fayetteville, AR 72704
}

Olivia S. Hines and John R. Clark

Department of Horticulture, University of Arkansas, 316 Plant Science, Fayetteville, AR 72701

Luke R. Howard and Cindi R. Brownmiller

Department of Food Science, University of Arkansas, 2650 North Young Avenue, Fayetteville, AR 72704

\section{Daniela M. Segantini \\ Department of Horticulture, University of Arkansas, 316 Plant Science, Fayetteville, AR 72701}

Lydia J.R. Lawless

Department of Food Science, University of Arkansas, 2650 North Young Avenue, Fayetteville, AR 72704

Additional index words. Rubus, descriptive, consumer, fruit, aromatics, appearance, composition, taste, nutraceutical

\begin{abstract}
Blackberries (Rubus subgenus Rubus Watson) are grown worldwide for commercial fresh markets. Physiochemical and sensory attributes were evaluated on fresh fruit of five blackberry cultivars (Natchez, Osage, Ouachita, Prime-Ark ${ }^{\circledR}$ 45, and Prime-Ark ${ }^{\circledR}$ Traveler) $^{\text {(n) }}$ and six advanced breeding selections from the University of Arkansas Fruit Breeding Program. The physiochemical attributes of blackberries were within a commercially acceptable range (soluble solids $=8 \%$ to $11 \%, \mathrm{pH}=3.0-3.6$, titratable acidity $=0.7 \%$ to $1.4 \%$, berry weight $=6$ to $14 \mathrm{~g}$, drupelets/berry $=50$ to 150 , and pyrenes/berry $=51$ to 115 ). 'Natchez' had the highest berry weight, berry length, drupelets/berry, and pyrenes/berry, whereas A-2453 was the lowest for these attributes. The highest nutraceutical levels were found in 'Osage' (total flavonols and total anthocyanins), A-2434 (total ellagitannins) and A-2453 (total phenolics). A trained descriptive sensory panel $(n=9)$ evaluated fresh blackberry attributes for appearance, basic tastes, feeling factors, aromatics, and texture using a 15-point scale $(0=$ less of the attribute; $\mathbf{1 5}=$ more of the attribute in terms of intensity). The descriptive panel identified 'Natchez' as having the largest descriptive size of berry with the highest overall aromatics and A-2453 as the smallest, glossiest, and firmest. Although A-2491 had the highest soluble solids, the descriptive panelists could not differentiate sweetness among the genotypes, but found A-2491 the least sour. A consumer sensory panel $(n=74)$ evaluated appearance, flavor, and texture attributes of blackberries on a 9-point verbal hedonic liking scale $(1=$ extremely dislike; $9=$ like extremely $)$ and 5 -point just about right $(\mathrm{JAR})$ scale $(1=$ not nearly enough; $3=\mathrm{JAR} ; 5$ = much too much). In terms of overall impression and overall flavor, A-2491 and 'Prime-Ark ${ }^{\circledR}$ Traveler' had the highest liking; average attributes for these blackberries were a berry weight of $9.1 \mathrm{~g}$, soluble solids of $10.0 \%$, titratable acidity of $0.95 \%$, and a soluble solids/titratable acid ratio of 11.9. 'Prime-Ark ${ }^{\circledR}$ Traveler' also had the highest liking for appearance and berry size. A-2453, the glossiest berry, had the highest liking for berry color. Consumer panelists liked the firmness of the blackberries including those that were very firm, such as A-2453, but did not indicate differences in liking among genotypes. Consumers found the size of 'Ouachita', 'Prime-Ark ${ }^{\circledR}$ Traveler', and 'Prime-Ark ${ }^{\circledR}$ 45' (berry weight $\approx 8.3 \mathrm{~g})$ JAR, but 'Natchez' $(14.3 \mathrm{~g})$ too large. Consumers found the sweetness and sourness of A-2491 JAR. Consumer overall impression and flavor of blackberries were positively correlated to consumer liking of berry shape and color and negatively correlated to the descriptive attributes for sourness, bitterness, green/unripe aromatic, and amount of seeds. Consumer liking of appearance was positively correlated with consumer liking of berry size, shape, color, and descriptive uniformity of color and glossiness. To produce a commercially marketed fresh-market blackberry, there are many characteristics that are important, but our data for these genotypes suggest that a desired blackberry should have a berry weight of 8-10 g, soluble solids of $9 \%$ to $11 \%$, titratable acidity of $0.9 \%$ to $1 \%$, and a soluble solids/ titratable acid ratio of 10 to 13 . However, optimum sugar and acidity levels require more investigation including other factors in flavor and aromatics. Evaluating the physiochemical and sensory attributes of fresh fruit is an important tool that can be used to determine commercial potential for selections and cultivars.
\end{abstract}

Blackberries (Rubus subgenus Rubus Watson) are a high-value specialty crop grown worldwide for fresh market and processing. Fresh blackberry fruit has potential for an increased role in commercial markets due to the increase of production and consumer demand for this flavorful, nutraceutical-rich fruit. In 2005, world blackberry production area was 20,036 ha and was projected to increase to over 27,000 ha by 2015 (Strik et al., 2007). The increase in production can be contributed in part to blackberry breeding programs that have enhanced desirable traits and reduced undesirable traits in plants and fruit. Since 1985, over 60 blackberry cultivars have been released from breeding programs in the United States (Clark, 1999; Clark and Finn, 2008). In 2014, 2469 ha of blackberries were harvested in the United States including $\approx 1400 \mathrm{t}$ of freshmarket blackberries (USDA, 2014).

In the southeastern United States, the University of Arkansas System Division of Agriculture has been the primary blackberry breeding program providing cultivars with unique and improved traits incorporated into adapted genotypes (cultivars and advanced, nonreleased selections). Breeding traits of interest in fresh-market blackberries include enhanced fruit quality, flavors, and shipping capabilities and plant thornlessness, productivity, adaptation/habit, and disease/pest resistance (Clark, 2005, 2008; Clark and Finn, 2008; Clark and Perkins-Veazie, 2011; Finn and Clark, 2012; Lewers et al., 2010). The breeding program released the first primocane-fruiting cultivars, plants that produce fruit on first-year canes in addition to second-year floricanes. 'Prime-Jim ${ }^{\circledR}$ ', 'Prime$\operatorname{Jan}^{\circledR}$ ', 'Prime-Ark ${ }^{\circledR} 45$ ', and more recently 'Prime-Ark ${ }^{\circledR}$ Traveler' are primocane-fruiting releases from the University of Arkansas (Clark and Finn, 2008).

Blackberry is an aggregate fruit comprised of drupelets surrounding a soft tissue receptacle or torus. The size of a blackberry is determined by the combination of torus size, drupelet number, and size of drupelets (Clark et al., 2007). Each drupelet has a thin exocarp, a fleshy mesocarp, and a hard, lignified endocarp (or pyrene) that encloses a single seed (TomlikWyremblewska et al., 2010). Pyrene characteristics are distinctive to each blackberry genotype and based on the shape of the raphe, have been classified into three groups: straight, concave, or convex (Wada and Reed, 2010; Wada et al., 2010). Slight variation of pyrene shape can occur in the same genotype, and the outer layer of the endocarp will have characteristic patterns of reticulation (TomlikWyremblewska et al., 2010; Wada et al., 2010). Pyrene shape and endocarp thickness influence perceived seediness when consumed (Takeda, 1993). Pyrene weight and pyrene number were positively correlated with blackberry fruit weight (Moore et al., 1974). Moore et al. (1975) found that pyrene size in blackberries is highly heritable with partial dominance for small pyrene size.

Like other dark-pigmented fruits, blackberries are a source of nutraceutical-rich 
components that can positively impact human health (Clark et al., 2002; Conner et al., 2005; de Souza et al., 2014; Howard and Hager, 2007; Manganaris et al., 2014; Moyer et al., 2002; Radočaj et al., 2014; ReyesCarmona, et al., 2005; Sariburun et al., 2010; Seeram, 2008; Sellappan, et al., 2002; Siriwoharn et al., 2004; Wang et al., 2009). High levels of anthocyanins, a polyphenolic antioxidant, naturally occur in blackberries and account for the dark red pigmentation of the fruit (Wang et al., 2009). Polyphenols, including anthocyanins, proanthocyanidins, flavonones, and flavonols, also have properties that could positively impact human health (Ness and Poulens, 1997; Prior et al., 1998; Reyes-Carmona et al., 2005; Steinmetz and Potter, 1996). Radočaj et al. (2014) investigated the nutraceutical content of seed oil extracted from dried blackberry press pomace. Despite their healthy properties, these potential nutraceutical components can impact fruit quality and sensory perception. Phenolic compounds are also relevant as they play a role in the bitterness, sweetness, or astringency of products and contribute to aroma (Tomás-Barberán and Espín, 2001).

Fruit attributes such as sweetness, tartness, flavor, and astringency along with color, firmness, and seediness are important to consumers (Clark et al., 2007; Clark and Finn, 2008, Hall et al., 2002). In general, consumers prefer fresh blackberries that are perceived as less "seedy" (fewer, smaller, and/or softer pyrenes). The structure, size, and number of pyrenes in the blackberry may influence mouthfeel of the blackberries when consumed (Clark et al., 2007). Small pyrene size $(<3.0 \mathrm{mg})$ is preferred in both freshmarket and processed blackberry products, and large pyrenes can be objectionable (Moore et al., 1975). Large pyrene size, based on weight, length or volume, and seediness is also undesirable in processed blackberry products (Takeda, 1993). Fresh-market blackberries can feel "seedy" when consumed, depending on pyrene attributes.

Harrison et al. (1999) established sensory descriptors for the flavor of raspberries and suggested the potential use of sensory characteristics for breeding selections. Some sensory research has been done to profile processing blackberries grown in the northwestern United States. Kurnianta et al. (2005) evaluated 10 thornless blackberry selections in comparison with the standard 'Marion' and developed a lexicon of 21 aroma descriptors for floral, fresh fruit, cooked fruit, vegetal, grainy, vinyl,

Received for publication 4 Feb. 2016. Accepted for publication 22 July 2016.

This research was funded by a Specialty Crop Block Grant from the Arkansas Agriculture Department, U.S. Department of Agriculture (12-25-B-1656). Additional support was provided by the Southern Region Small Fruit Consortium and the University of Arkansas Dale Bumpers College Honors Grant and Honors College Grant Programs.

${ }^{1}$ Corresponding author. E-mail: rthrelf@uark.edu. wet cardboard, and basic tastes/mouth feel. Du et al. (2010b) found the 11 thornless blackberries genotypes from the Pacific Northwest had diverse descriptive sensory aroma profiles. Du et al. (2010a) also profiled the flavor of 'Marion' blackberries using instrumental and sensory analysis. de Souza et al. (2014) profiled sensory attributes of blackberries that had been frozen/thawed using different methods as compared with a fresh control. Cavender et al. (2014) investigated the sensory profiles and antioxidant properties of blackberries grown using different weed management strategies.

More research is needed to determine attributes of the fresh-market blackberries that consumers want for blackberries that are or will be commercially available. Therefore, the objective of this work was to evaluate the physiochemical and sensory attributes of fresh-market blackberries developed from southeastern U.S. germplasm and grown in the southeastern United States.

\section{Materials and Methods}

\section{Fruit}

Blackberries were harvested from the University of Arkansas Fruit Research Station, Clarksville. The blackberries were harvested at the shiny-black stage of ripeness and were free of major blemishes, flaws, or damage. Fruit were hand-harvested from the plants in June 2014. About $4 \mathrm{~kg}$ of fruit was harvested from each of the 11 genotypes, five cultivars (Natchez, Osage, Ouachita, Prime-Ark ${ }^{\circledR} 45$, and Prime-Ark ${ }^{\circledR}$ Traveler), and six selections (A-2416, A-2418, A-2434, A-2450, A-2453, and A-2491). Six genotypes were harvested on 23 June and five genotypes were harvested on 1 July. Air temperatures were the same for both harvests. On the first harvest date, there was a light rain early in the morning, but the harvest was delayed until the fruit was dry. On both dates, the fruit was harvested by 11:00 AM. Fruit was harvested directly into 240 -g (pint), low-profile vented clamshells, placed in chilled coolers and transported to the Department of Food Science, Fayetteville. A random sample of fruit was collected from the harvest clamshells and used for the sensory and physiochemical analysis. A $100 \mathrm{~g}$ sample of each genotype was frozen $\left(-20^{\circ} \mathrm{C}\right)$ in triplicate for physiochemical analysis, and the remainder was stored overnight in clamshells at $2{ }^{\circ} \mathrm{C}$ for sensory analysis.

\section{Physiochemical analysis}

Evaluations for physiochemical attributes of blackberries were done at the Department of Food Science, University of Arkansas, Fayetteville. Three samples of $\approx 100 \mathrm{~g}$ of berries from each genotype were stored at $-20^{\circ} \mathrm{C}$ until analyzed.

Berry and pyrene attributes. From the frozen berries, three randomly selected berries per genotype and replication were used to determine berry attributes (individual weight, length, width, and drupelets/berry) and pyrene attributes (number/berry and weight/berry). The three-berry samples were weighed on a digital scale (Explorer, Ohaus Corporation, Parsippany, NJ), and the width and height (at the widest or longest sections of the berry) of each blackberry was measured with a digital caliper.

To determine pyrene attributes, a $0.1 \mathrm{~mL}$ of Pec5L enzyme (Scott Laboratories, Petaluma, CA) was added to each bag containing the three-berry frozen sample to break down the skin and pulp. Once the berries thawed, they were hand mashed in the bags. After $1.5 \mathrm{~h}$ at $21^{\circ} \mathrm{C}$, distilled water was added to each bag. The samples were then poured into a strainer. Under running water, the pulp was mashed against the strainer until only pyrenes remained. The pyrenes were placed onto paper towels and dried at ambient temperature $\left(21^{\circ} \mathrm{C}\right)$ for $1.5 \mathrm{~h}$. The pyrenes for each three-berry sample were counted and weighed. The pyrenes were further dried in a laboratory oven (Isotemp ${ }^{\circledR}$, Model 655F; Fischer Scientific, Pittsburg, PA) at $55{ }^{\circ} \mathrm{C}$ for $\approx 24 \mathrm{~h}$, then removed and weighed.

Composition analysis. Three-berry samples of each genotype were used in triplicate to determine the soluble solids, $\mathrm{pH}$, and titratable acidity. Samples were thawed, placed in cheesecloth, and squeezed to extract the juice from the berries. Titratable acidity and $\mathrm{pH}$ were measured by an 877 Titrino Plus (Metrohm AG, Herisau, Switzerland) standardized to $\mathrm{pH} 2.0,4.0,7.0$, and 10.0 buffers. Titratable acidity was determined using $6 \mathrm{~g}$ of juice diluted with $50 \mathrm{~mL}$ of deionized, degassed water by titration with $0.1 \mathrm{~N}$ sodium hydroxide to an endpoint of $\mathrm{pH}$ 8.2; results were expressed as percent citric acid. Total soluble solids (expressed as percent) were measured with a Bausch \& Lomb Abbe Mark II refractometer (Scientific Instrument, Keene, NH).

Nutraceutical analysis. Nutraceutical analysis was done on each genotype in triplicate. To obtain sample extracts, samples (25 g) were homogenized with $20 \mathrm{~mL}$ of acetone/ water/acetic (70:29.5:0.5 v/v/v) with a Euro Turrax T18 Tissuemizer (Tekmar-Dohrman Corp., Mason, OH). The samples were filtered through Miracloth (Calbiochem, La Jolla, $\mathrm{CA}$ ), the filter cakes were isolated and the extraction was repeated. This extraction process was repeated with methanol/water/formic acid $(60: 37: 3 \mathrm{v} / \mathrm{v} / \mathrm{v})$. The filtrates were adjusted to a final volume of $250 \mathrm{~mL}$ with extraction solvent to assure complete extraction of the nutraceutical compounds.

Ellagitannins and flavonols. Sample extracts $(3 \mathrm{~mL})$ were dried using a Speed Vac concentrator (ThermoSavant, Holbrook, NY) and resuspended in $0.5 \mathrm{~mL}$ of extraction solvent. The reconstituted samples were passed through $0.45 \mu \mathrm{m}$ polytetrafluoroethylene syringe filters (Varian, Inc., Palo Alto, CA) before high-performance liquid chromatography (HPLC) analysis. The ellagitannins were analyzed on a Waters Alliance HPLC system (Milford, MA) equipped with a Waters model 996 photodiode array detector and Millennium version 3.2 software (Waters Corp., Milford, MA). Separation was performed using a Phenomenex Aqua $5 \mu \mathrm{m} \mathrm{C}_{18}(250 \times$ 
$4.6 \mathrm{~mm}$ ) column (Torrance, CA) with a binary gradient of $2 \%$ acetic acid for mobile phase $\mathrm{A}$ and $0.5 \%$ acetic acid in water/acetonitrile $(1: 1 \mathrm{v} / \mathrm{v})$ for mobile phase $\mathrm{B}$ at a flow rate of $1.0 \mathrm{~mL} \cdot \mathrm{min}^{-1}$. A linear gradient was run from $10 \%$ to $55 \% \mathrm{~B}(0-50 \mathrm{~min})$, from $55 \%$ to $100 \%$ $\mathrm{B}(50-60 \mathrm{~min})$, and from $100 \%$ to $10 \% \mathrm{~B}$ (60$65 \mathrm{~min})$. The ellagitannins and flavonols were identified on the basis of comparison of HPLC retention times to our previous HPLC results obtained using the identical HPLC conditions and liquid chromatography-mass spectrometry analysis (Hager et al., 2008a; 2010). The ellagitannin peaks were quantified at $255 \mathrm{~nm}$ as ellagic acid equivalents using external calibration curves of ellagic acid, with results expressed as milligram ellagic acid equivalents per $100 \mathrm{~g}$ of fresh berry weight. The flavonols were quantified at $360 \mathrm{~nm}$ as rutin with results expressed as equivalents per $100 \mathrm{~g}$ of fresh berry weight.

Anthocyanins. Sample extracts $(3 \mathrm{~mL})$ were dried using a Speed Vac concentrator and resuspended in $2 \mathrm{~mL}$ of $3 \%$ formic acid. The reconstituted samples were filtered through $0.45 \mu \mathrm{m}$ PTFE syringe filters (Varian, Inc., Palo Alto, CA) before HPLC analysis. The anthocyanin analysis by HPLC was performed based on previous methods (Cho et al., 2004; Hager et al., 2008b) with a $250 \times 4.6 \mathrm{~mm}$ Symmetry $\mathrm{C}_{18}$ column (Waters Corp.). The mobile phase consisted of a binary gradient of 5\% formic acid (A) and 100\% methanol (B). The flow rate was $1.0 \mathrm{~mL} \cdot \mathrm{min}^{-1}$ with a linear gradient from $2 \%$ to $60 \%$ B over $60 \mathrm{~min}$. The anthocyanin peaks were quantified at $510 \mathrm{~nm}$ using a photodiode array detector. All anthocyanins (cyanidin 3-glucoside, cyanidin 3-rutinoside, cyanidin 3-xyloside, cyanidin 3-malonylglucoside, and cyanidin 3-dioxalylglucoside) were quantified as cyanidin 3-glucoside (acy) equivalents with total monomeric anthocyanins results expressed as milligrams per $100 \mathrm{~g}$ of fresh berry weight.

Total phenolics. Total phenolics were measured using the Folin-Ciocalteu assay (Slinkard and Singleton, 1977) with a gallic acid standard and a consistent standard curve based on serial dilutions. Absorbencies were measured at $760 \mathrm{~nm}$, and results were expressed as milligrams per $100 \mathrm{~g}$ of fresh berry weight of gallic acid equivalents.

\section{Descriptive and consumer sensory analysis}

Descriptive and consumer sensory analyses of the fresh blackberries were performed at the Sensory and Consumer Research Center at the University of Arkansas, Fayetteville, the day after each harvest. Six genotypes were sensory evaluated in the first week of harvest, then five genotypes were evaluated after harvest the next week. The genotypes were evaluated on two different dates to avoid panel fatigue. Before serving, the blackberries were gently rinsed, placed on trays lined with paper towels, and allowed to air-dry. For descriptive and consumer sensory analysis, each panelist evaluated three to five berries for each genotype. The blackberry samples were served sequentially monadically at room temperature $\left(24{ }^{\circ} \mathrm{C}\right)$ with random three-digit codes in a randomized complete block design. Panelists were instructed to cleanse their palates with unsalted crackers and water between samples. Expectorant cups were also provided. In both the descriptive and consumer analysis, the panelists evaluated aspects of the pyrenes in the blackberries, but used the term "seeds."

Descriptive analysis. The trained panelists for this descriptive sensory analysis had over 8 years of experience working together to descriptively evaluate a wide range of products and were paid on an hourly basis. The panelists were trained to use a modified Sensory Spectrum ${ }^{\circledR}$ method, an objective method for describing the intensity of attributes in products using references for the attributes. The descriptive panelists $(n=9)$ developed a lexicon of sensory terms for blackberries through consensus (Table 1; Fig. 1) during orientation and practice sessions and evaluated the genotypes in duplicate. Serving order was randomized across each duplication (replication) to prevent presentation order bias. Descriptive panelists were trained with an absolute scale anchored by references. The panelists assessed each attribute per genotype and replication at a particular intensity according to the reference points and using the universal aromatic scale. The descriptive panel identified fresh blackberry attributes for appearance $(\mathrm{n}=8)$, basic tastes $(n=3)$, feeling factors $(n=2)$, aromatics $(\mathrm{n}=8)$, and texture $(\mathrm{n}=7)$ and evaluated those attributes using a 15-point scale $(0=$ less of the attribute; $15=$ more of the attribute in terms of intensity). The uniformity of the berries for flavor and texture was included in the lexicon and evaluated, but the data were not presented. The reference for the color of the blackberries was from the Royal Horticulture Society Colour Chart (fifth edition, London) Black Group 203A = 15.0 score for intensity. The $203 \mathrm{~A}$ had values of $L^{*}=34.32, C^{*}=5.16, h=284.04, a=$ 0.87 , and $b=3.65$.

Consumer analysis. Consumers $(\mathrm{n}=74)$ were recruited from a database $(\mathrm{n} \approx 5500)$ based on consumption and purchasing habits and liking of fresh blackberries. Consumers selected for this study indicated they purchase fresh blackberries at least once a month and that they like blackberries. All 74 consumers evaluated the 11 genotypes and were paid with gift card incentives. The consumer panel was comprised of 13 males and 61 females ages 18 to over 65 years from a range of incomes from less than $\$ 15,000$ to more than $\$ 100,000$. The consumers were also asked questions regarding purchase and consumption habits for fresh blackberries, where multiple responses were allowed. The consumers evaluated appearance, size, shape, color, overall impression, overall flavor, and firmness of blackberries on a 9-point verbal hedonic scale $(1=$ extremely dislike; $9=$ like extremely). The consumers also evaluated size, blackberry flavor, sweetness, sourness, bitterness, astringency, firmness, crispness, and seediness of blackberries on a 5-point JAR scale $(1=$ not nearly enough; $3=$ JAR; 5 = much too much). The consumers evaluated the appearance of blackberry attributes before tasting the samples. Consumer responses were collected via Compusense 5 (version 4.6; Compusense, Guelph, Canada).

\section{Statistical design and analyses}

After harvest, the fruit from each of the 11 genotypes was randomly selected for physiochemical and sensory analysis. The physiochemical and sensory data were analyzed by analysis of variance. Associations among all dependent variables were determined using multivariate pairwise correlation coefficients of the mean values using JMP ${ }^{\circledR}$ (version 12.0; SAS Institute, Cary, NC). Correlations were used to test the relationship between/within physicochemical attributes and sensory attributes, with significant correlations reported $(P=0.05)$. To relate consumer liking data with descriptive and analytical data, principal component regression was performed using $\mathrm{JMP}^{\circledR}$.

Physiochemical. For the physiochemical data, the genotypes were evaluated in triplicate and data were analyzed using $\mathrm{JMP}^{\circledR}$. Tukey's honestly significant difference was used for mean separation $(P=0.05)$.

Sensory. For descriptive analysis, the genotypes were evaluated by nine panelists in duplicate. For the consumer analysis, the genotypes were evaluated by 74 consumer panelists. Least significant difference was used for mean separation $(P=0.05)$ of the sensory data in a customized reporting system. To identify blackberry attribute improvements, penalty analysis was performed using the JAR data for the highest scored genotype in terms of overall liking using $\mathrm{JMP}^{\circledR}$ and Microsoft Excel (Microsoft Office 365; Microsoft, Seattle, WA).

\section{Results and Discussion}

The challenge of this research was to plan a complete study for a fresh-market crop with variable harvest times and unpredictable weather for harvest, particularly when arranging with sensory evaluations. Eleven blackberry genotypes (five cultivars and six selections) from the University of Arkansas Fruit Breeding Program were evaluated for physiochemical and sensory attributes. This is one of the first research publications on fresh blackberry genotypes to comprehensively compare physiochemical attributes (berry and pyrene attributes, composition, and nutraceutical content) of blackberries with sensory attributes (descriptive and consumer sensory).

\section{Physiochemical analysis}

Berry and pyrene attributes. The berry and pyrene attributes of the blackberries varied significantly by genotype, particularly size attributes. The blackberries had berry weights from 6.0 to $14.3 \mathrm{~g}$, berry lengths from 27.5 to $43.7 \mathrm{~mm}$, berry widths from 22.2 to $26.9 \mathrm{~mm}$, drupelets/berry from 50.2 to 125.8 , 
Table 1. Lexicon developed for fresh-market blackberry attributes by a descriptive sensory panel with nine trained panelists.

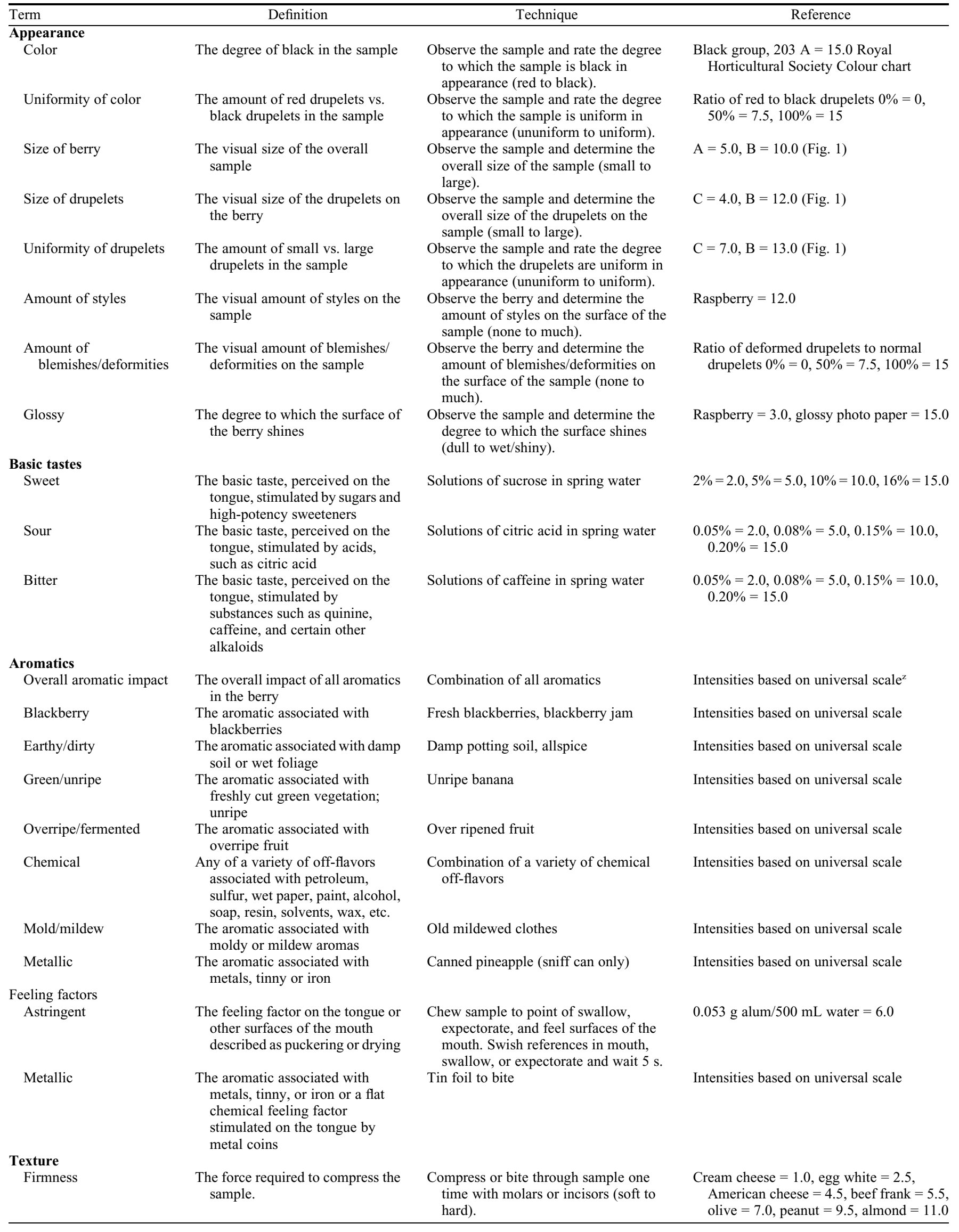


Table 1. (Continued) Lexicon developed for fresh-market blackberry attributes by a descriptive sensory panel with nine trained panelists.

\begin{tabular}{|c|c|c|c|}
\hline Term & Definition & Technique & Reference \\
\hline Size of seeds & $\begin{array}{l}\text { The amount of space a particle fills } \\
\text { in your mouth. How big are the } \\
\text { seeds? }\end{array}$ & $\begin{array}{l}\mathrm{A}=\text { sesame seeds, } \mathrm{B}=\text { dill deeds (small } \\
\text { to large). }\end{array}$ & $\mathrm{A}=5.0, \mathrm{~B}=9.0$ \\
\hline Amount of seeds & The number of seeds in your mouth & $\begin{array}{l}0.4 \mathrm{~g} \text { dill seed } / 10 \mathrm{~g} \text { apple sauce; } \approx 182 \\
\text { seeds (none to much). }\end{array}$ & $\mathrm{B}=7.0$ \\
\hline Toothpack & $\begin{array}{l}\text { The amount of product packed into } \\
\text { the crowns of your teeth after } \\
\text { mastication }\end{array}$ & $\begin{array}{l}\text { Chew sample } 4-5 \text { times, expectorate and } \\
\text { feel the surface of the crowns of the } \\
\text { teeth to evaluate (none to much). }\end{array}$ & $\begin{array}{l}\text { Cap'n Crunch }{ }^{\circledR} \text { cereal }=5.0 \text {, Heath } \\
\text { bar }^{\circledR}=10.0\end{array}$ \\
\hline Loose particles & $\begin{array}{l}\text { The amount of particles remaining } \\
\text { in and on the surface of the } \\
\text { mouth after swallowing }\end{array}$ & $\begin{array}{l}\text { Chew sample with molars, swallow and } \\
\text { evaluate (none to much). }\end{array}$ & Carrot $=10.0$ \\
\hline Uniformity of texture & $\begin{array}{l}\text { How uniform is the entire sample } \\
\text { in texture }\end{array}$ & $\begin{array}{l}\text { After tasting all four berries on your } \\
\text { plate, how uniform is the texture over } \\
\text { the four berries? (Ununiform to } \\
\text { uniform) }\end{array}$ & $\begin{array}{l}\text { Ratio of low to high } 0 \%=0,50 \%=7.5 \\
\quad 100 \%=15\end{array}$ \\
\hline
\end{tabular}

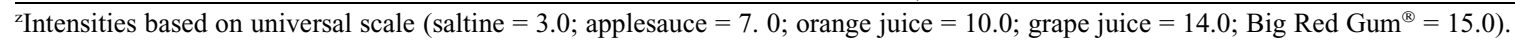

pyrene weight/berry from 0.18 to $0.43 \mathrm{~g}$, and pyrenes/berry from 51.0 to 115.0 (Table 2). 'Natchez' had the greatest berry weight, berry length, drupelets/berry, pyrene weight/berry, and pyrenes/berry. 'Natchez' has been one of the most widely planted of the Arkansasreleased cultivars in the past 5 years due to its large size and early ripening (J.R. Clark, personal communication). A-2453 had the smallest berry weight, berry length, drupelets/ berry, pyrene weight/berry, and pyrenes/ berry. Although A-2453 had lower yields than other University of Arkansas cultivars limiting its commercial potential, it is valuable as a parent due to unique firmness and postharvest potential (J.R. Clark, personal communication).

There were many correlations within berry and pyrene attributes. Berry weight and length was significantly correlated $(r=0.73-0.93)$ to drupelets/berry, pyrene weight/berry, and pyrenes/berry. Moore et al. (1974) also found that pyrene weight and number were positively correlated with blackberry weight. Drupelets/ berry was correlated to pyrene weight/berry $(r=0.88)$ and pyrenes/berry $(r=0.96)$, whereas pyrene weight/berry and pyrenes/ berry were also highly correlated $(r=0.96)$. The bigger the berry, like 'Natchez', especially in length, the more the drupelets, and pyrenes, whereas the opposite occurred with a smaller berry like A-2453.

Composition. Composition values were within a commercially acceptable range for fresh blackberries (Table 2). The blackberries had soluble solids levels $8.1 \%$ to $11.0 \%$, pH values from 3.0 to 3.6 , titratable acidity from $0.7 \%$ to $1.4 \%$, and soluble solids/titratable acidity ratio of 6.2 to 16.5 . When working on blackberry development in the Arkansas breeding program, the goal of the blackberry breeding program is to have a titratable acidity no greater than $1 \%$ (J.R. Clark, personal communication). Reyes-Carmona et al. (2005) evaluated blackberry genotypes in Mexico and United States and found soluble solids from $7.5 \%$ to $16.1 \%, \mathrm{pH}$ from 2.3 to 4.3 and titratable acidity from $1.0 \%$ to $4.2 \%$; according to these authors, blackberry composition was strongly dependent on genotype rather than climate or season.

The influence of soluble solids and titratable acidity on perceived flavor is complex in a blackberry matrix. A-2491 had the highest soluble solids and A-2418 had the lowest, while A-2418 had the highest titratable acidity and 'Ouachita' had the lowest (Table 2). Soluble solids/titratable acidity ratio is often used to determine the balance of perceived sweetness or sourness in a product. 'Ouachita' had the highest soluble solids/acid ratio (16.5), A-2418 had the lowest (6.2), but A2491 (highest soluble solids) had a soluble solids/titratable acidity ratio of 13.5 . According to Crisosto and Crisosto (2005), the relationship between titratable acidity and soluble solids has an important role in consumer acceptance of other fruits like peaches and nectarines [Prunus persica (L.) Batsch]; in their study consumer acceptance was influenced by the balance between titratable acidity and soluble solids rather than soluble solids alone. Compared with other fruits, blackberries have a low soluble solids/titratable acidity ratio. de Souza et al. (2014) showed that the average soluble solids/titratable acidity ratio of blackberries was 6.7 , whereas the optimum soluble solids/acid ratio for muscadine grapes (Vitis rotundifolia Michaux) was $\approx 30$, with 25 to 35 being acceptable (Flora, 1979; Walker et al., 2001). The soluble solids/titratable acidity ratios of blackberries are lower than muscadine grapes because the soluble solids of blackberries are $\approx 50 \%$ lower than muscadines and the titratable acidity of blackberries is more than muscadines. The $\mathrm{pH}$ of the blackberries was negatively correlated to the titratable acidity $(r=-0.91)$, but soluble solids were not significantly correlated to $\mathrm{pH}$ or titratable acidity. As expected, the soluble solids/titratable acidity ratio was positively correlated to the soluble solids $(r=0.66)$ and $\mathrm{pH}(r=0.84)$ and negatively correlated to titratable acidity $(r=-0.95)$. Thus, in terms of solids/titratable acidity ratio, we consistently found weak correlations with soluble solids compared with stronger correlations with titratable acidity because titratable acidity can have four times the impact on ratio for blackberries.

Nutraceutical content. The blackberries had total ellagitannins content from 20.6 to $45.4 \mathrm{mg}$ ellagic acid equivalent $/ 100 \mathrm{~g}$, total flavonols from 7.7 to $16.1 \mathrm{mg}$ rutin equivalent/ $100 \mathrm{~g}$, total anthocyanins from 55.4 to $247 \mathrm{mg} \mathrm{acy} / 100 \mathrm{~g}$, and total phenolics from 434 to $606 \mathrm{mg}$ gallic acid equivalent $/ 100 \mathrm{~g}$ (Table 3). The phenolic contents varied greatly among genotypes. Siriwoharn et al. (2004) evaluated blackberry genotypes from the northwestern United States and found similar results with total ellagitannins from 7.7 to $27.2 \mathrm{mg}$ ellagic acid equivalent $/ 100 \mathrm{~g}$, total flavonols from 4.0 to 8.7 rutin equivalent $\mathrm{mg} / 100 \mathrm{~g}$, total anthocyanins from 131 to $256 \mathrm{mg}$ acy/100 $\mathrm{g}$, and total phenolics from 682 to $1040 \mathrm{mg}$ gallic acid equivalent/ 100 g. Benvenuti et al. (2004) found 67 to $119 \mathrm{mg}$ acy/100 $\mathrm{g}$ for total anthocyanins and 193 to $352 \mathrm{mg}$ gallic acid equivalent/ $100 \mathrm{~g}$ for total phenolics in blackberries. 'Osage' had the highest total flavonols and 


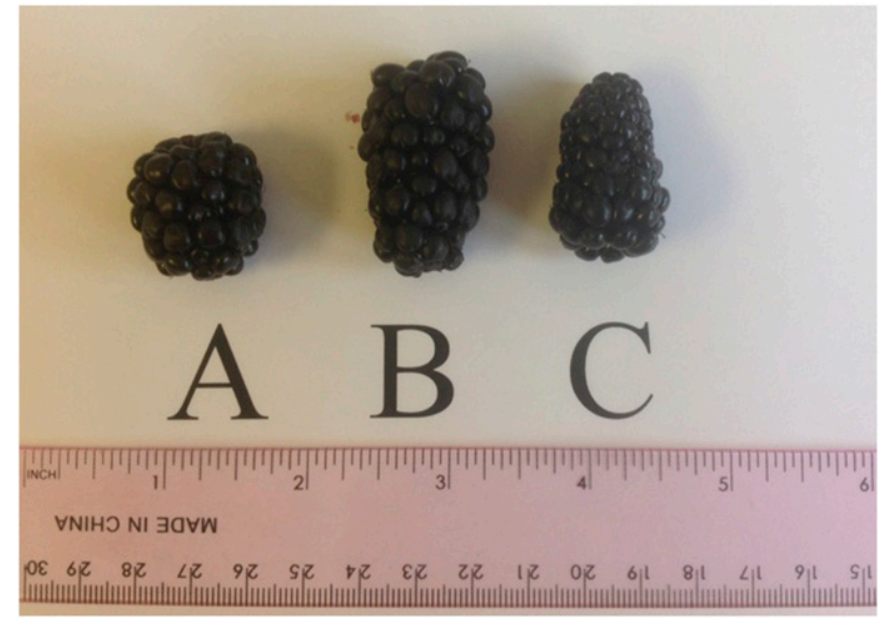

Fig. 1. Reference used by the descriptive panel to score the size of blackberries $(A=5$ with berry length of $25 \mathrm{~mm}$ and $\mathrm{B}=10$ with berry length of $40 \mathrm{~mm})$, size of drupelets of the blackberries $(\mathrm{C}=4$ and $\mathrm{B}=12)$, and uniformity of drupelets of the blackberries $(\mathrm{C}=7$ and $\mathrm{B}=13)$ on a 15-point scale.

total anthocyanins. 'Prime-Ark ${ }^{\circledR}$ Traveler' had the lowest total flavonols and total anthocyanins, and 'Ouachita' had the lowest total ellagitannins and total phenolics. A-2434 had the highest total ellagitannins. A-2453 had the highest total phenolics, but was the smallest berry with a relatively high soluble solids level and low titratable acidy. Total phenolics was slightly correlated to total ellagitannins $(r=$ $0.61)$ and total flavonols $(r=0.75)$.

Comparisons among physiochemical attributes. There were not many significant correlations among the physiochemical attributes (berry and pyrene attributes vs. composition vs. nutraceutical content). However, titratable acidity and soluble solids/titratable acidity ratio was correlated with pyrene weight/ berry ( $r=0.71$ and $r=-0.72$, respectively) and pyrenes/berry ( $r=0.65$ and $r=-0.68$, respectively), indicating that blackberries with more and larger pyrenes had higher titratable acidity and lower soluble solids/titratable acidity ratio among these genotypes. The correlation between titratable acidity and soluble solids/ titratable acidity ratio and pyrenes was significant, titratable acidity and soluble solids/titratable acidity ratio differences could be attributed to the number of pyrenes. Since titratable acidity is a significant attribute for blackberries, the relationship between pyrenes and titratable acidity should be further investigated. The blackberry $\mathrm{pH}$ was negatively correlated with berry length $(r=-0.64)$, but this was the only size attribute of the berry with correlations to composition. With the genotypes in our study, the bigger the blackberry, the lower the $\mathrm{pH}$ and higher titratable acidity. This relationship may not be found if other genotypes are investigated.

\section{Sensory analysis}

Descriptive sensory analysis. The lexicon developed by the descriptive panel included references used by the panelists to evaluate the appearance, basic tastes, feeling factors, aromatics, and texture of fresh blackberries (Table 1). This lexicon can be used by other programs to evaluate the attributes of fresh blackberries or modified for use with other fresh fruit.

Appearance attributes. The appearance attributes of blackberries are an important attribute for fresh market because consumers can purchase blackberries based on appearance attributes of the blackberries evaluated included color, uniformity of color, size of berry, size of drupelets, uniformity of drupelets, amount of styles, amount of blemishes, and glossiness (Table 4). The color of the blackberries was scored in the black range. The uniformity of color was $87 \%$ to $94 \%$ indicating mostly black berry and drupelet color. Some red drupelets were present on some genotypes of the berries stored overnight at $2{ }^{\circ} \mathrm{C}$ before evaluation. The descriptive panel scored the size of the berries from 7.1 to 12.1 on the 15 -point scale as compared with standards with berry length of $25 \mathrm{~mm}=5$ to $40 \mathrm{~mm}=10$ (Fig. 1). 'Natchez' was the largest berry and A-2453 the smallest. A-2491 had larger and more uniform drupelets. 'Prime-Ark ${ }^{\circledR} 45$ ' had the smallest drupelets and 'Ouachita' had the least uniform drupelets on a berry. A-2453 was perceived to have the least amount of styles on a berry, whereas 'Ouachita' had the most. The amount of blemishes on the berries were low $(0 \%$ to $25 \%)$ with A-2453 the least. The glossiness of the berry was based on standards of commercially purchased fresh raspberries $=5$ (dull $/$ matte in appearance) and glossy photo paper $=15$ with values of the genotypes ranging from 8.4 to 12.2. The descriptive panel identified A-2453 as the glossiest berry (Fig. 2A).

Basic tastes. The panelists evaluated the basic tastes (sweet, sour, and bitter) of the blackberries (Table 5). The panelists found the sweetness of the blackberries ranged from 3.6 to 4.4 with a $2=2 \%$ sucrose solution and $5=5 \%$ sucrose solution. Although berry soluble solids levels ranged from $8 \%$ to $11 \%$, panelists found no significant differences appearance in a clamshell container. The in descriptive sweetness among the genotypes. In terms of sourness, the berries ranged from 3.8 to 5.4 with $2=0.05 \%$ citric acid solution and $5=0.08 \%$ citric acid solution. The blackberries were very low in bitterness (1.9 to 2.6 with a $2=0.05 \%$ solution of caffeine in water). A-2491 was rated as the least sour and bitter and A-2416 as the most sour. As compared with A-2491, A-2416 had $1.5 \%$ less soluble solids, $0.3 \%$ more titratable acidity, and 30\% less soluble solids/titratable ratio.

Feeling factors. The panelists evaluated the feeling factors (astringent and metallic) of the blackberries and found no differences among the genotypes. The genotypes were about the same level of astringency with a reference of $0.53 \mathrm{~g}$ alum $/ 500 \mathrm{~mL}$ water $(\approx 6)$. The metallic feeling factors (biting into tin foil as a reference) of the blackberries were low.

Aromatic attributes. The aromatic attributes (volatiles perceived by the olfactory system while chewing a sample in the mouth) of the blackberries included overall aromatic impact, blackberry, earthy/dirty, green/ unripe, overripe/fermented, chemical, mold/ mildew, and metallic (Table 5). The intensity of overall aromatics ranged from 7.6 to 8.2, with 'Natchez' having the highest intensity. There was no difference in the genotypes for blackberry, mold/mildew, or metallic aromatics. The overripe/fermented, chemical, earthy/dirty, and green/unripe aromatic intensities were very low. Wang et al. (2005) found that berries grown in two different regions (Oregon vs. Arkansas) had similar composition, but had differences in volatile aroma compounds. The aromatic attributes play a key role in the "taste" of the blackberries, and overall aromatic impact and blackberry aromatics were the highest scored intensities in the midrange of the 15-point scale.

Texture attributes. The texture attributes included firmness, moisture release, popping/ bursting, size of seeds, amount of seeds, toothpack, and loose particles (Table 5). The descriptive panel differentiated firmness of the berries ( 3.1 to 4.2 with references of egg white $=2.5$ and American cheese $=4.5$ ) and popping/bursting (degree the drupelets pop/burst as compared with pomegranate seeds $=12$ ). A-2453 was the most firm, and 'Natchez' and 'Prime-Ark ${ }^{\circledR} 45$ ' were the least firm (Fig. 2B). A-2453 had a significantly higher popping/bursting attribute as compared with the other genotypes, which is a unique trait of this genotype. The berries were moist (7.9 to 8.6) as compared with cucumber $=8$ for moisture release, but there was no differences among genotypes. The panelists did not detect any toothpack attributes for the blackberries. The panelists could not identify differences in the size of the pyrenes, the amount of pyrenes, or loose particles of the blackberry genotypes evaluated. The pyrenes were similar in size to a sesame seed with less pyrenes as compared with the reference (182 dill seeds/10 g applesauce). Although numerous and large 


\begin{tabular}{|c|c|c|c|c|c|c|c|c|c|c|}
\hline Genotype & $\begin{array}{l}\text { Berry } \\
\text { wt (g) }\end{array}$ & $\begin{array}{c}\text { Berry } \\
\text { length }(\mathrm{mm})\end{array}$ & $\begin{array}{c}\text { Berry } \\
\text { width (mm) }\end{array}$ & $\begin{array}{c}\text { Drupelets/ } \\
\text { berry }\end{array}$ & $\begin{array}{c}\text { Pyrene } \\
\text { wt }(\mathrm{g}) / \text { berry }\end{array}$ & $\begin{array}{c}\text { Pyrenes/ } \\
\text { berry }\end{array}$ & $\begin{array}{c}\text { Soluble } \\
\text { solids (\%) }\end{array}$ & $\mathrm{pH}$ & $\begin{array}{c}\text { Titratable } \\
\text { acidity }(\%)^{z}\end{array}$ & $\begin{array}{c}\text { Soluble } \\
\text { solids/titratable } \\
\text { acidity ratio }\end{array}$ \\
\hline A-2416 & $11.06 \mathrm{ab}^{\mathrm{y}}$ & $36.80 \mathrm{ab}$ & $24.81 \mathrm{ab}$ & $88.55 \mathrm{~b}$ & $0.28 \mathrm{bcd}$ & $83.22 \mathrm{~b}$ & $9.47 \mathrm{ab}$ & $3.16 \mathrm{ab}$ & $1.01 \mathrm{ab}$ & $9.54 \mathrm{ab}$ \\
\hline A-2418 & $9.66 \mathrm{bc}$ & $32.90 \mathrm{bc}$ & $25.31 \mathrm{ab}$ & $84.22 \mathrm{~b}$ & $0.38 \mathrm{ab}$ & $94.22 \mathrm{ab}$ & $8.07 \mathrm{~b}$ & $3.08 \mathrm{~b}$ & $1.35 \mathrm{a}$ & $6.17 \mathrm{~b}$ \\
\hline A-2450 & $9.05 \mathrm{bcd}$ & $37.32 \mathrm{ab}$ & $22.16 \mathrm{~b}$ & $92.22 \mathrm{~b}$ & $0.32 a b c$ & $92.00 \mathrm{ab}$ & $8.93 \mathrm{ab}$ & $3.00 \mathrm{~b}$ & $1.16 \mathrm{ab}$ & $7.68 \mathrm{ab}$ \\
\hline A-2453 & $6.01 \mathrm{~d}$ & $27.47 \mathrm{c}$ & $24.85 \mathrm{ab}$ & $50.22 \mathrm{c}$ & $0.18 \mathrm{~d}$ & $51.00 \mathrm{c}$ & $10.63 \mathrm{a}$ & $3.37 \mathrm{ab}$ & $0.75 \mathrm{ab}$ & $14.63 \mathrm{ab}$ \\
\hline A-2491 & $9.70 \mathrm{bc}$ & $36.76 \mathrm{ab}$ & $23.07 \mathrm{ab}$ & $81.78 \mathrm{~b}$ & $0.28 \mathrm{bcd}$ & $84.78 \mathrm{~b}$ & $10.97 \mathrm{a}$ & $3.20 \mathrm{ab}$ & $0.97 \mathrm{ab}$ & $13.49 \mathrm{ab}$ \\
\hline Ouachita & $8.80 \mathrm{bcd}$ & $29.08 \mathrm{bc}$ & $26.56 \mathrm{ab}$ & $69.78 \mathrm{bc}$ & $0.23 \mathrm{~cd}$ & $66.78 \mathrm{bc}$ & $10.60 \mathrm{a}$ & $3.43 \mathrm{ab}$ & $0.66 \mathrm{~b}$ & $16.46 \mathrm{a}$ \\
\hline Prime-Ark ${ }^{\circledR} 45$ & $7.64 \mathrm{~cd}$ & $33.43 \mathrm{bc}$ & $22.71 \mathrm{ab}$ & $85.78 \mathrm{~b}$ & $0.32 \mathrm{abc}$ & $90.22 \mathrm{ab}$ & $9.47 \mathrm{ab}$ & $3.38 \mathrm{ab}$ & $0.81 \mathrm{ab}$ & $12.30 \mathrm{ab}$ \\
\hline Prime-Ark ${ }^{\circledR}$ Traveler & $8.45 \mathrm{bcd}$ & $30.80 \mathrm{bc}$ & $22.20 \mathrm{~b}$ & $76.11 \mathrm{~b}$ & $0.27 \mathrm{bcd}$ & $78.44 \mathrm{bc}$ & $8.97 \mathrm{ab}$ & $3.20 \mathrm{ab}$ & $0.92 \mathrm{ab}$ & $10.23 \mathrm{ab}$ \\
\hline$P$ value & $<0.0001$ & $<0.0001$ & 0.0065 & $<0.0001$ & $<0.0001$ & $<0.0001$ & 0.0065 & 0.0020 & 0.0135 & 0.0365 \\
\hline
\end{tabular}

${ }^{2}$ Calculated as percent citric acid.

${ }^{y}$ Genotypes were evaluated in triplicate. Means with different letter(s) for each attribute are significantly different $(P<0.05)$ using Tukey's honestly significant difference.

Table 3. Nutraceutical attributes ${ }^{z}$ for blackberry genotypes, Clarksville, AR, 2014.

\begin{tabular}{|c|c|c|c|c|}
\hline Genotype & $\begin{array}{c}\text { Total ellagitannins } \\
\text { (mg ellagic acid equivalents } / 100 \mathrm{~g} \text { ) }\end{array}$ & $\begin{array}{c}\text { Total flavonols } \\
\text { (mg rutin equivalents } / 100 \mathrm{~g} \text { ) }\end{array}$ & $\begin{array}{l}\text { Total anthocyanins } \\
(\mathrm{mg} \text { acy/100 } \mathrm{g})\end{array}$ & $\begin{array}{c}\text { Total phenolics } \\
\text { (mg gallic acid equivalents } / 100 \mathrm{~g})\end{array}$ \\
\hline A-2416 & $41.96 \mathrm{ab}^{\mathrm{y}}$ & $12.10 \mathrm{a}$ & $191.10 \mathrm{abc}$ & $603.13 \mathrm{a}$ \\
\hline A-2418 & $43.10 \mathrm{ab}$ & $12.76 \mathrm{a}$ & $181.86 \mathrm{abcd}$ & $555.66 \mathrm{ab}$ \\
\hline A-2434 & $45.43 \mathrm{a}$ & $12.76 \mathrm{a}$ & $206.56 \mathrm{ab}$ & $603.63 \mathrm{a}$ \\
\hline A-2450 & $27.36 \mathrm{c}$ & $12.26 \mathrm{a}$ & $199.23 \mathrm{abc}$ & $573.83 \mathrm{ab}$ \\
\hline A-2453 & $39.90 \mathrm{ab}$ & $15.20 \mathrm{a}$ & $119.96 \mathrm{cde}$ & $606.33 \mathrm{a}$ \\
\hline A-2491 & $30.20 \mathrm{abc}$ & $9.33 \mathrm{a}$ & $107.70 \mathrm{de}$ & $518.73 \mathrm{ab}$ \\
\hline Natchez & $38.76 \mathrm{ab}$ & $8.96 \mathrm{a}$ & $183.76 \mathrm{abcd}$ & $528.50 \mathrm{ab}$ \\
\hline Osage & $29.46 \mathrm{abc}$ & $16.10 \mathrm{a}$ & $246.53 \mathrm{a}$ & $580.96 \mathrm{ab}$ \\
\hline Ouachita & $20.63 \mathrm{c}$ & $8.93 \mathrm{a}$ & $173.03 \mathrm{abcd}$ & $434.20 \mathrm{~b}$ \\
\hline Prime-Ark ${ }^{\circledR} 45$ & $36.86 \mathrm{abc}$ & $13.30 \mathrm{a}$ & $146.46 \mathrm{bcd}$ & $517.20 \mathrm{ab}$ \\
\hline Prime-Ark $^{\circledR}$ Traveler & $33.86 \mathrm{abc}$ & $7.70 \mathrm{a}$ & $55.36 \mathrm{e}$ & $463.80 \mathrm{ab}$ \\
\hline$P$ value & 0.0005 & 0.1524 & $<0.0001$ & 0.0078 \\
\hline
\end{tabular}

${ }^{2}$ Nutraceuticals of blackberries calculated as fresh weight for total ellagitannins; total flavonols; total anthocyanins [mg cyanidin 3-glucoside (acy)/100 g]; total phenolics.

${ }^{y}$ Genotypes were evaluated in triplicate. Means with different letter(s) for each attribute are significantly different $(P<0.05)$ using Tukey's honestly significant difference.

Table 4. Descriptive sensory appearance attributes for blackberry genotypes evaluated on a 15 -point scale $(0=$ less of the attribute; $15=$ more of the attribute in terms of intensity), Clarksville, AR, 2014.

\begin{tabular}{|c|c|c|c|c|c|c|c|c|}
\hline Genotype & Color & $\begin{array}{l}\text { Uniformity } \\
\text { of color }\end{array}$ & Size of berry & Size of drupelets & $\begin{array}{c}\text { Uniformity of } \\
\text { drupelets }\end{array}$ & Amount of styles & $\begin{array}{c}\text { Amount of } \\
\text { blemishes }\end{array}$ & Glossiness \\
\hline A-2418 & $13.99 \mathrm{ab}$ & $13.70 \mathrm{ab}$ & $10.41 \mathrm{~b}$ & $11.31 \mathrm{abc}$ & $10.97 \mathrm{abcd}$ & $3.72 \mathrm{~cd}$ & $3.75 \mathrm{a}$ & $10.37 \mathrm{de}$ \\
\hline A-2434 & $13.61 \mathrm{abcd}$ & $13.60 \mathrm{ab}$ & $10.71 \mathrm{~b}$ & $10.87 \mathrm{bcd}$ & $9.68 \mathrm{ef}$ & $4.58 \mathrm{ab}$ & $3.86 \mathrm{a}$ & $9.77 \mathrm{e}$ \\
\hline A-2453 & $14.10 \mathrm{a}$ & $14.13 \mathrm{a}$ & $7.10 \mathrm{e}$ & $11.41 \mathrm{ab}$ & $11.55 \mathrm{ab}$ & $2.29 \mathrm{e}$ & $1.64 \mathrm{c}$ & $12.17 \mathrm{a}$ \\
\hline A-2491 & $13.64 \mathrm{abcd}$ & $13.81 \mathrm{ab}$ & $10.72 \mathrm{~b}$ & $11.96 \mathrm{a}$ & $11.61 \mathrm{a}$ & $5.02 \mathrm{a}$ & $2.03 \mathrm{bc}$ & $11.62 \mathrm{ab}$ \\
\hline Natchez & $13.50 \mathrm{bcd}$ & $13.66 \mathrm{ab}$ & $12.08 \mathrm{a}$ & $11.61 \mathrm{ab}$ & $11.17 \mathrm{abc}$ & $4.47 \mathrm{abc}$ & $2.42 \mathrm{~b}$ & $11.39 \mathrm{bc}$ \\
\hline Prime-Ark ${ }^{\circledR} 45$ & $13.26 \mathrm{~cd}$ & $13.31 \mathrm{bc}$ & $8.64 \mathrm{~cd}$ & $9.45 \mathrm{f}$ & $10.04 \mathrm{def}$ & $3.71 \mathrm{~cd}$ & $2.04 \mathrm{bc}$ & $10.22 \mathrm{de}$ \\
\hline Prime-Ark ${ }^{\circledR}$ Traveler & $13.91 \mathrm{ab}$ & $13.77 \mathrm{ab}$ & $9.35 \mathrm{c}$ & $10.29 \mathrm{de}$ & $10.39 \mathrm{cdef}$ & $4.27 \mathrm{abc}$ & $2.14 \mathrm{bc}$ & $10.86 \mathrm{~cd}$ \\
\hline$P$ value & 0.023 & 0.016 & $<0.0001$ & $<0.0001$ & $<0.0001$ & $<0.0001$ & $<0.0001$ & $<0.0001$ \\
\hline
\end{tabular}

${ }^{\mathrm{z}}$ Genotypes were evaluated in duplicate by nine trained panelists. Means with different letter(s) for each attribute are significantly different $(P<0.05)$ using least significant difference.

pyrenes are thought to be objectionable, the panelists could not differentiate these attributes for these genotypes.

\section{Consumer sensory analysis}

The consumer panel $(n=74)$ evaluated appearance, size, shape, color, overall impression, overall flavor, and firmness of fresh blackberries on a 9-point verbal hedonic scale and blackberry flavor, sweetness, tartness, bitterness, astringency, firmness, crispness, and seediness of blackberries on a 5-point JAR scale (Tables 6 and 7). Consumers in this study indicated that they purchased fresh blackberries at a grocery store $(73 \%)$, farmers market $(55 \%)$, pickyour-own farm $(32 \%)$, other locations $(12 \%)$, natural food stores $(8 \%)$, and food co-ops $(5 \%)$. Twenty-six percent of the consumers indicated that they consumed fresh blackberries once per week to once per month, whereas $4 \%$ claimed they consumed fresh blackberries daily. Consumers indicated that they used fresh blackberries by consuming fresh $(95 \%)$, baking/cooking $(68 \%)$, freezing $(43 \%)$, preserves/jams $(27 \%)$, and other (4\% smoothies and cocktails). The consumers were asked what drives them to purchase fresh blackberries with quality $(77 \%)$, availability, seasonality and price $(66 \%)$, and consistency $(8 \%)$ as responses. Consumers were also asked what drives them to not purchase fresh blackberries, and the responses were price $(77 \%)$, quality $(72 \%)$, availability $(34 \%)$, seasonality $(24 \%)$, and consistency $(3 \%)$. 
Hedonic liking scale. All of the attributes evaluated by consumers for the blackberry genotypes in this study were scored from 5 to

$8(5=$ neither like nor dislike; $6=$ like slightly; $7=$ like moderately; and $8=$ like very much) on the hedonic scale (Table 6).

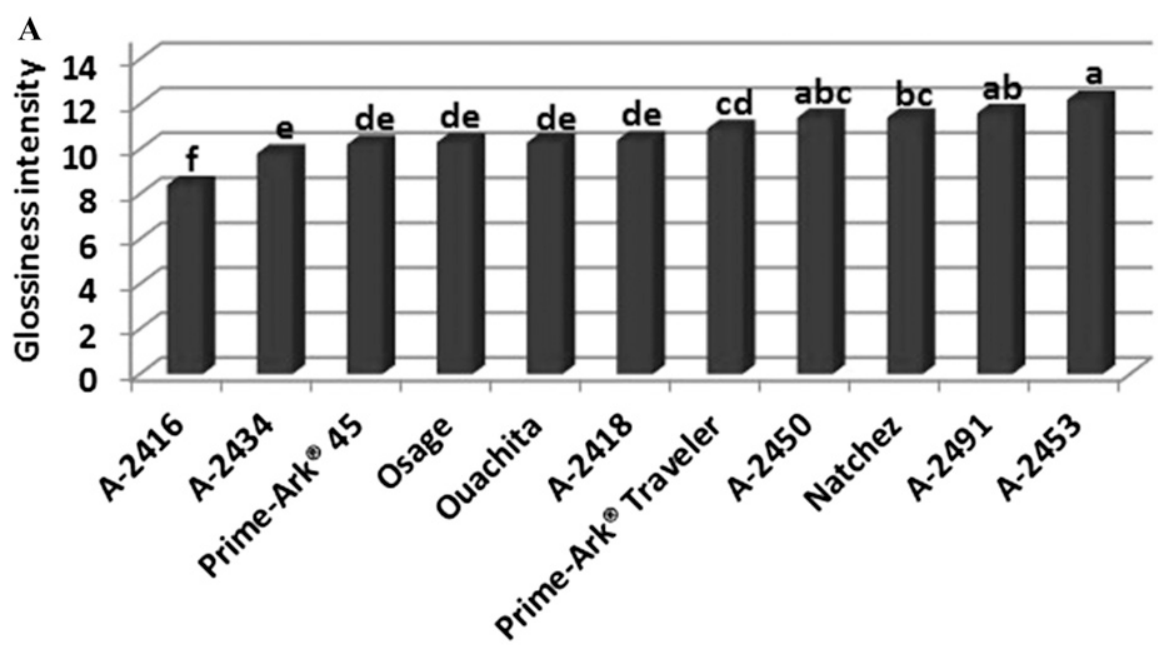

\section{Genotypes}

B

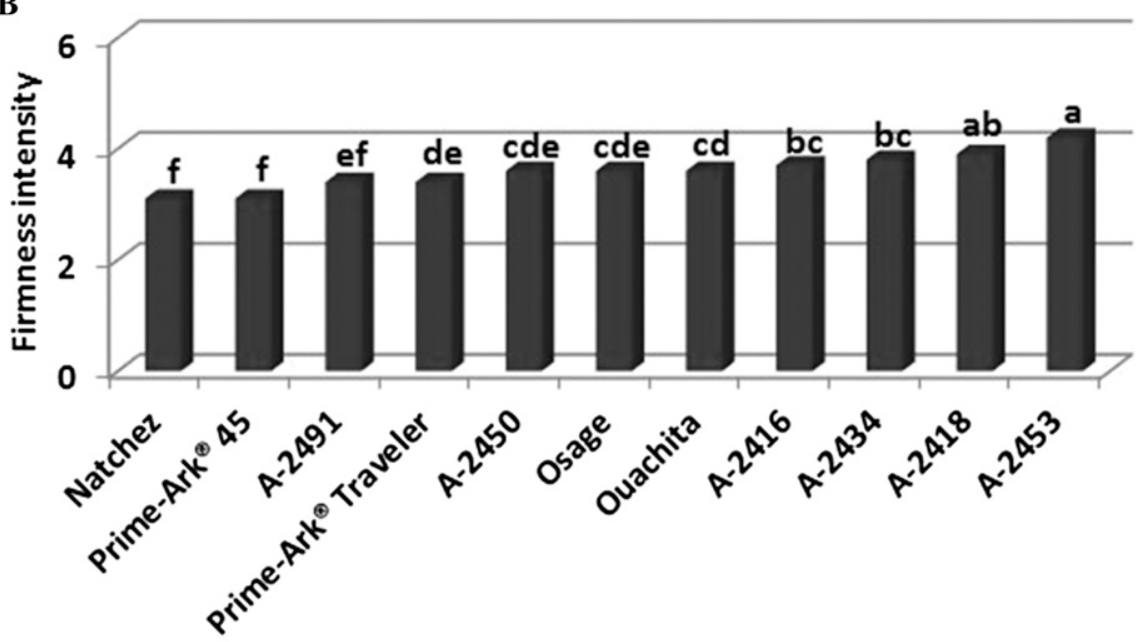

Genotypes

Fig. 2. Descriptive sensory glossiness intensity (A) and firmness intensity (B) attribute ${ }^{\mathrm{z}}$ for blackberry genotypes evaluated on a 15 -point scale $(0=$ less of the attribute; $15=$ more of the attribute in terms of intensity), 2014. ${ }^{\mathrm{z}}$ Genotypes evaluated by nine trained panelists in duplicate. Means with different letter(s) for each attribute are significantly different $(P<0.05)$ using least significant difference.

Berry appearance, size, shape, and color were the first attributes evaluated by the consumers and the consumers scored these attributes 6.6 to 7.9. 'Prime-Ark ${ }^{\circledR}$ Traveler' ( $8.5 \mathrm{~g}$ berry) had the highest liking scores for appearance, whereas A-2416 (11 g berry) had the lowest for appearance, size, and color. Consumers liked a medium-sized berry vs. a larger berry. Consumer panelists liked the firmness of the genotypes, but found no differences among genotypes. This was a noteworthy finding, as A-2453 was a uniquely firm berry, and it was of interest to determine if consumers considered this blackberry too firm. From the hedonic liking data, the percent of the panelist's responses were also calculated on a collapsed scale (data not shown). The collapsed scale had panelists that did not like the attribute ( 1 to 4 on the hedonic scale) and those that like the attribute ( 6 to 9 on the hedonic scale). For instance, $95 \%$ and $92 \%$ of the consumers liked 'Prime$\mathrm{Ark}^{\circledR} 45$ ' and A-2453, respectively, where the percent of the consumers scored the attribute on the hedonic score of 6 to 9 . For instance, the consumers liked the appearance of 'Prime-Ark ${ }^{\circledR} \quad 45$ ' (95\%) and A-2453 (92\%), which was the total percent from the hedonic scores 6 to 9 . 'Prime-Ark ${ }^{\circledR}$ Traveler' and 'Prime-Ark ${ }^{\circledR}$ 45 ' had the highest liking scores for size (Fig. 3A), and $91 \%$ of the consumers liked the size of 'Prime-Ark ${ }^{\circledR} 45$ ' and A-2491. 'Natchez' and A-2416 (the two largest berries) had $19 \%$ to $20 \%$ dislike of the size. Consumers did not find differences in the shape of the berry, but $82 \%$ to $91 \%$ of the consumers liked the shape. Consumers ( $86 \%$ to $97 \%$ ) indicated that A-2453 had the highest liking for berry color.

In terms of overall impression and overall flavor, A-2491 and 'Prime-Ark ${ }^{\circledR}$ Traveler' had the highest liking values, whereas A-2434 had the lowest (Table 6; Fig. 3B). A-2491 and 'Prime-Ark ${ }^{\circledR}$ Traveler' had high liking values and had roughly a $9 \mathrm{~g}$ berry weight with $10 \%$ soluble solids, $0.95 \%$ titratable acidity, and a soluble solids/titratable acid ratio of 11.8 . About $79 \%$ to $89 \%$ of the consumers liked A-2491 and 'Prime-Ark ${ }^{\circledR}$ Traveler' and about $42 \%$ of the consumers disliked A-2434 for overall impression and

Table 5. Descriptive sensory basic tastes, aromatic attributes, and texture attributes for blackberry genotypes evaluated on a 15 -point scale $(0=$ less of the attribute; $15=$ more of the attribute in terms of intensity), Clarksville, AR, 2014

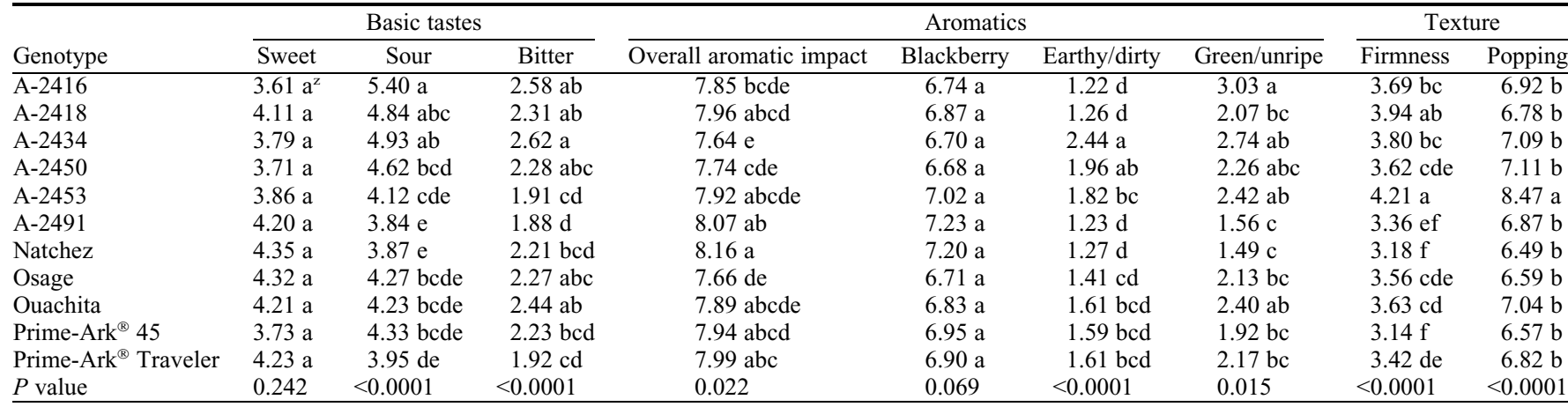

${ }^{\mathrm{z}}$ Genotypes were evaluated in duplicate by nine trained panelists. Means with different letter(s) for each attribute are significantly different $(P<0.05)$ using least significant difference. 
Table 6 . Consumer sensory attributes for blackberry genotypes evaluated on a 9 -point hedonic scale $(1=$ dislike extremely; $5=$ neither like nor dislike; $9=$ like extremely), Clarksville, AR, 2014.

\begin{tabular}{|c|c|c|c|c|c|c|c|}
\hline Genotype & Appearance & Size & Shape & Color & Overall impression & Overall flavor & Firmness \\
\hline A-2416 & $6.76 \mathrm{~d}^{\mathrm{z}}$ & $6.62 \mathrm{c}$ & $6.96 \mathrm{a}$ & $7.12 \mathrm{~d}$ & $5.88 \mathrm{ef}$ & $5.76 \mathrm{ef}$ & $6.82 \mathrm{a}$ \\
\hline A-2418 & $7.27 \mathrm{bc}$ & $6.93 \mathrm{bc}$ & $7.28 \mathrm{a}$ & $7.64 \mathrm{bc}$ & $6.16 \mathrm{de}$ & $6.07 \mathrm{de}$ & $7.20 \mathrm{a}$ \\
\hline A-2434 & $7.09 \mathrm{~cd}$ & $7.01 \mathrm{bc}$ & $7.08 \mathrm{a}$ & $7.59 \mathrm{bc}$ & $5.42 \mathrm{f}$ & $5.27 \mathrm{f}$ & $6.81 \mathrm{a}$ \\
\hline A- 2450 & $7.39 \mathrm{abc}$ & $7.11 \mathrm{ab}$ & $6.95 \mathrm{a}$ & $7.61 \mathrm{bc}$ & $5.88 \mathrm{ef}$ & $5.70 \mathrm{ef}$ & $6.88 \mathrm{a}$ \\
\hline A-2453 & $7.59 \mathrm{ab}$ & $7.16 \mathrm{ab}$ & $7.31 \mathrm{a}$ & $7.93 \mathrm{a}$ & $6.59 \mathrm{bcd}$ & $6.51 \mathrm{~cd}$ & $6.95 \mathrm{a}$ \\
\hline A-2491 & $7.46 \mathrm{abc}$ & $7.34 \mathrm{ab}$ & $7.35 \mathrm{a}$ & $7.86 \mathrm{ab}$ & $7.28 \mathrm{a}$ & $7.26 \mathrm{a}$ & $7.31 \mathrm{a}$ \\
\hline Natchez & $7.34 \mathrm{abc}$ & $6.95 \mathrm{bc}$ & $7.26 \mathrm{a}$ & $7.66 \mathrm{abc}$ & $7.07 \mathrm{ab}$ & $6.92 \mathrm{abc}$ & $6.99 \mathrm{a}$ \\
\hline Osage & $7.35 \mathrm{abc}$ & $7.01 \mathrm{bc}$ & $7.14 \mathrm{a}$ & $7.82 \mathrm{abc}$ & $6.91 \mathrm{abc}$ & $6.73 \mathrm{abc}$ & $6.78 \mathrm{a}$ \\
\hline Ouachita & $7.19 \mathrm{c}$ & $7.20 \mathrm{ab}$ & $7.26 \mathrm{a}$ & $7.54 \mathrm{c}$ & $6.58 \mathrm{bcd}$ & $6.55 \mathrm{bcd}$ & $7.26 \mathrm{a}$ \\
\hline Prime-Ark ${ }^{\circledR} 45$ & $7.65 \mathrm{a}$ & $7.46 \mathrm{a}$ & $7.50 \mathrm{a}$ & $7.70 \mathrm{abc}$ & $6.51 \mathrm{~cd}$ & $6.41 \mathrm{~cd}$ & $6.96 \mathrm{a}$ \\
\hline Prime-Ark $^{\circledR}$ Traveler & $7.68 \mathrm{a}$ & $7.49 \mathrm{a}$ & $7.46 \mathrm{a}$ & $7.88 \mathrm{ab}$ & $7.18 \mathrm{a}$ & $7.09 \mathrm{ab}$ & $7.11 \mathrm{a}$ \\
\hline$P$ value & $<0.0001$ & 0.003 & 0.054 & $<0.0001$ & $<0.0001$ & $<0.0001$ & 0.157 \\
\hline
\end{tabular}

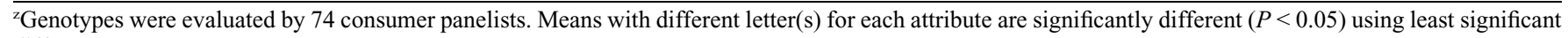
difference.

Table 7. Percent (\%) of consumer sensory attributes for blackberry genotypes on a collapsed 5-point just about right (JAR) ${ }^{\mathrm{z}}$ scale, Clarksville, AR, 2014.

\begin{tabular}{|c|c|c|c|c|c|c|c|c|c|c|c|c|c|c|c|c|c|c|}
\hline \multirow[b]{2}{*}{ Genotype } & \multicolumn{3}{|c|}{ Size } & \multicolumn{3}{|c|}{ Sweetness } & \multicolumn{3}{|c|}{ Sourness } & \multicolumn{3}{|c|}{ Bitterness } & \multicolumn{3}{|c|}{ Blackberry aromatic } & \multicolumn{3}{|c|}{ Firmness } \\
\hline & $\begin{array}{l}\text { Too } \\
\text { small }\end{array}$ & JAR & $\begin{array}{l}\text { Too } \\
\text { big }\end{array}$ & $\begin{array}{c}\text { Not } \\
\text { sweet }\end{array}$ & JAR & $\begin{array}{c}\text { Too } \\
\text { sweet }\end{array}$ & $\begin{array}{l}\text { Not } \\
\text { sour }\end{array}$ & JAR & $\begin{array}{c}\text { Too } \\
\text { sour }\end{array}$ & $\begin{array}{l}\text { Not } \\
\text { bitter }\end{array}$ & JAR & $\begin{array}{c}\text { Too } \\
\text { bitter }\end{array}$ & $\begin{array}{l}\text { Too } \\
\text { low }\end{array}$ & JAR & $\begin{array}{l}\text { Too } \\
\text { high }\end{array}$ & $\begin{array}{l}\text { Not } \\
\text { firm }\end{array}$ & JAR & $\begin{array}{l}\text { Too } \\
\text { firm }\end{array}$ \\
\hline $\mathrm{A}-2416$ & 3 & 54 & 43 & 66 & 33 & 1 & 2 & 33 & 65 & 1 & 60 & 39 & 31 & 51 & 18 & 26 & 69 & 5 \\
\hline A-2418 & 5 & 54 & 41 & 61 & 39 & 0 & 5 & 36 & 59 & 4 & 55 & 41 & 31 & 57 & 12 & 7 & 89 & 4 \\
\hline A-2434 & 4 & 66 & 30 & 74 & 26 & 0 & 7 & 24 & 69 & 1 & 31 & 68 & 38 & 38 & 24 & 15 & 78 & 7 \\
\hline A-2450 & 4 & 62 & 34 & 84 & 16 & 0 & 1 & 27 & 72 & 0 & 35 & 65 & 42 & 39 & 19 & 12 & 72 & 16 \\
\hline A-2453 & 30 & 65 & 5 & 56 & 43 & 1 & 18 & 54 & 28 & 7 & 70 & 23 & 35 & 59 & 6 & 7 & 66 & 24 \\
\hline A-2491 & 8 & 65 & 27 & 28 & 70 & 1 & 6 & 79 & 15 & 6 & 78 & 16 & 18 & 74 & 8 & 14 & 85 & 1 \\
\hline Natchez & 0 & 31 & 69 & 47 & 52 & 1 & 15 & 47 & 38 & 4 & 72 & 24 & 36 & 51 & 13 & 35 & 62 & 3 \\
\hline Osage & 26 & 65 & 9 & 41 & 55 & 4 & 10 & 68 & 22 & 8 & 81 & 11 & 32 & 64 & 4 & 32 & 68 & 0 \\
\hline Ouachita & 15 & 77 & 8 & 52 & 47 & 1 & 5 & 57 & 38 & 1 & 65 & 34 & 31 & 61 & 8 & 9 & 84 & 7 \\
\hline Prime-Ark ${ }^{\circledR} 45$ & 11 & 74 & 15 & 64 & 35 & 1 & 7 & 46 & 47 & 8 & 50 & 42 & 34 & 49 & 17 & 16 & 80 & 4 \\
\hline Prime-Ark ${ }^{\circledR}$ Traveler & 7 & 76 & 17 & 39 & 61 & 0 & 5 & 66 & 29 & 4 & 68 & 28 & 31 & 66 & 3 & 20 & 74 & 6 \\
\hline
\end{tabular}

${ }^{\mathrm{z}}$ Genotypes were evaluated by 74 consumer panelists. The 5 -point JAR scale $(1=$ much too little; $2=$ too little; $3=\mathrm{JAR} ; 4=$ too much; $5=$ much too much) was collapsed to Too Low, JAR, and Too Much.

overall flavor. A-2434 had a $9 \mathrm{~g}$ berry weight with $9.7 \%$ soluble solids, $1.2 \%$ titratable acidity, and a soluble solids/titratable acidity ratio of 9.1 .

$J A R$ scale. For analysis, the JAR data were collapsed to "Too Low", JAR, and "Too Much" (Table 7). Ideally in JAR evaluations, it is desired that at least $75 \%$ of participants consider an attribute JAR. Seventy-seven percent of the consumers found 'Ouachita' (8.8 g weight, $29 \mathrm{~mm}$ length, and $27 \mathrm{~mm}$ width) JAR in terms of blackberry size, followed closely by 'Prime-Ark ${ }^{\circledR}$ Traveler' and 'Prime-Ark ${ }^{\circledR} 45$ '. Consumers found A2491 JAR for astringency ( $89 \%)$ and sourness (78\%). Firmness and crispness had similar results with $89 \%$ of the consumers finding A2418 JAR. 'Natchez' was 90\% JAR for seediness. 'Prime-Ark ${ }^{\circledR}$ Traveler' and A2491 had JAR for sweetness of $61 \%$ and $70 \%$, respectively.

Examining the attributes in the "Too Low" or "Too Much" categories can also provide guidance on attributes for genotypes that need improvements for commercial potential. Attributes with more than $15 \%$ in either the "Too Low" or "Too Much" categories need to be examined. About $69 \%$ of the consumers found 'Natchez' (14 g weight, $44 \mathrm{~mm}$ length, and $26 \mathrm{~mm}$ width) too large. Consumers found A-2450 not sweet $(84 \%)$ and too sour (72\%); A-2450 had a soluble solids/titratable acidity ratio of 7.7 . Consumers found A-2434 too astringent (45\%) and too bitter (69\%). Consumers found A-2453 too seedy (36\%) and too firm (24\%) and 'Natchez' too soft (35\%). Consumers might have found A-2453 "seedy" because it was a small, firm genotype, whereas 'Natchez' was a large, soft genotype.

To further identify blackberry attribute improvements, penalty analysis was performed using the JAR data for the highest scored genotype in terms of overall liking. Penalties consider the mean drop (difference in liking between JAR attributes and "Too Low" or "Too Much") and the proportion of individuals in each of those categories. To increase the commercial potential for future blackberry developments, we can take the most-liked genotype (A-2491) and perform penalty analysis to define the attributes of A-2491 that were too low or too high. By identifying the penalties on the highest scoring genotype, we can identify areas of improvement for blackberries. A-2491 had penalties for "Too Little" crispness, sweetness, and blackberry flavor and "Too Much" bitterness and sourness. Penalties for these attributes range from -0.19 to -0.74 meaning that these attributes were of borderline concern according to standardized penalty analysis procedures (ASTM, 2009). According to this analysis, blackberry improvements to this genotype should include an increase in sweetness and blackberry flavor and decreased sourness and bitterness. If one examines the most-liked blackberry genotype for needed improvements, then the breeding efforts could focus on the potential to create the "perfect" blackberry. Increased liking of blackberries increases consumer repurchase rates in commercial markets.

\section{Comparisons within sensory attributes}

Consumer overall impression and overall flavor for the blackberries was highly correlated $(r=0.99)$. Both were positively correlated to consumer liking of shape and color and descriptive sweetness and blackberry flavor and negatively correlated to descriptive sourness, bitterness, green/unripe, and amount of seeds. Consumer liking of blackberry appearance was positively correlated with consumer liking of berry size $(r=0.86)$, shape $(r=0.75)$, and color $(r=0.88)$ and descriptive uniformity of color $(r=0.63)$ and glossiness $(r=0.75)$ of the blackberries and negatively correlated to the amount of descriptive blemishes $(r=-0.83)$.

\section{Comparisons between physiochemical and sensory}

Correlations and principal component analysis were used to determine the relationship between the physiochemical and sensory data. Berry weight, berry length, drupelet number/berry, and pyrenes/berry were positively correlated to descriptive size of berry ( $r=0.88$ to 0.91 ). Descriptive firmness and popping/bursting were negatively correlated to drupelets/berry $(r=-0.61$ to -0.65$)$. The soluble solids content of the blackberries was not correlated to any of the sensory data. The 
descriptive size of the berries was negatively correlated to $\mathrm{pH}(r=-0.75)$ and positively correlated to titratable acidy $(r=0.74)$. Total phenolics and total flavonols were negatively correlated with consumer liking of firmness of the blackberries and negatively correlated with descriptive overall aromatic impact $(r=$ -0.61). Although individual phenolic acids in blackberries were not measured, they could impact the overall aromatics. Total phenolics and total anthocyanins were negatively correlated to the consumer liking of size of berry and shape of berry. Total anthocyanins were positively correlated to descriptive bitterness of the blackberries ( $r=$ 0.74). Soares et al. (2013) suggested that anthocyanins and hydrolysable tannins could be the major phenolic compounds responsible for the bitterness in fruits and derived products where malvidin-3-glucoside activated and $\beta$-1,2,3,4,6-penta-O-galloyl-Dglucopyranose activated the human bitter taste receptors.

For the principal component analysis, three principal components explaining $62.4 \%$ of variance of physicochemical and descriptive data were identified using means as the data matrix (Table 8). Overall liking scores were regressed against the three principal components to determine positive and negative drivers of consumer liking for fresh blackberries. Significant effects were found for principal components 1 and $3(P=0.0003$ and 0.0130 , respectively). Liking of fresh blackberries was highest when attributes loading negatively on principal 1 and positively on principal 3 were highest. Positive and negative drivers of liking were identified for these blackberry genotypes. The positive drivers in principal component 1 were glossiness, loose particles, overall aromatic impact, blackberry aromatic, and uniformity of drupelets associated with the advanced selection A-2491, whereas the negative drivers were bitterness, sourness, amount of blemishes, amount of seeds, green/unripe, and metallic associated with A-2434. Though not significant, the principal component 2 had non drivers of firmness and chemical associated with A-2453 and drupelets/berry, pyrenes/berry, berry weight, size of berry, and moisture release associated with 'Natchez'. The positive drivers in principal component 3 were berry width, sweetness, $\mathrm{pH}$, and amount of styles associated with 'Ouachita' and 'Osage', whereas the negative drivers were associated with A-2450. Since over $70 \%$ of the consumer panelists indicated that they purchased blackberries in a grocery store, it is important to determine the drivers of liking to increase commercial potential.

\section{Conclusions}

This research provided insight into physiochemical attributes of fresh blackberries and how these attributes are perceived by consumers. The descriptive and consumer sensory panels identified and evaluated marketable attributes of fresh blackberries. Although firmness of blackberries has the potential to positively influence the freshmarket shipping industry, the appearance attributes, such as size, shape, color, and glossiness of the blackberries can positively influence consumer purchasing. In this study of blackberry genotypes with a berry

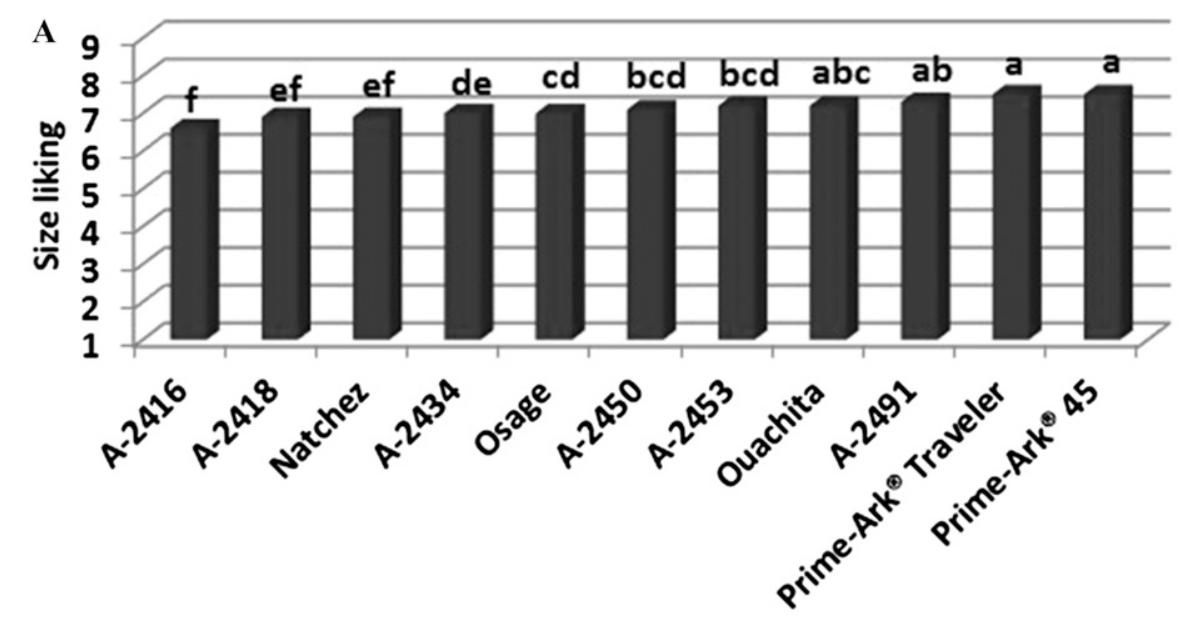

Genotypes

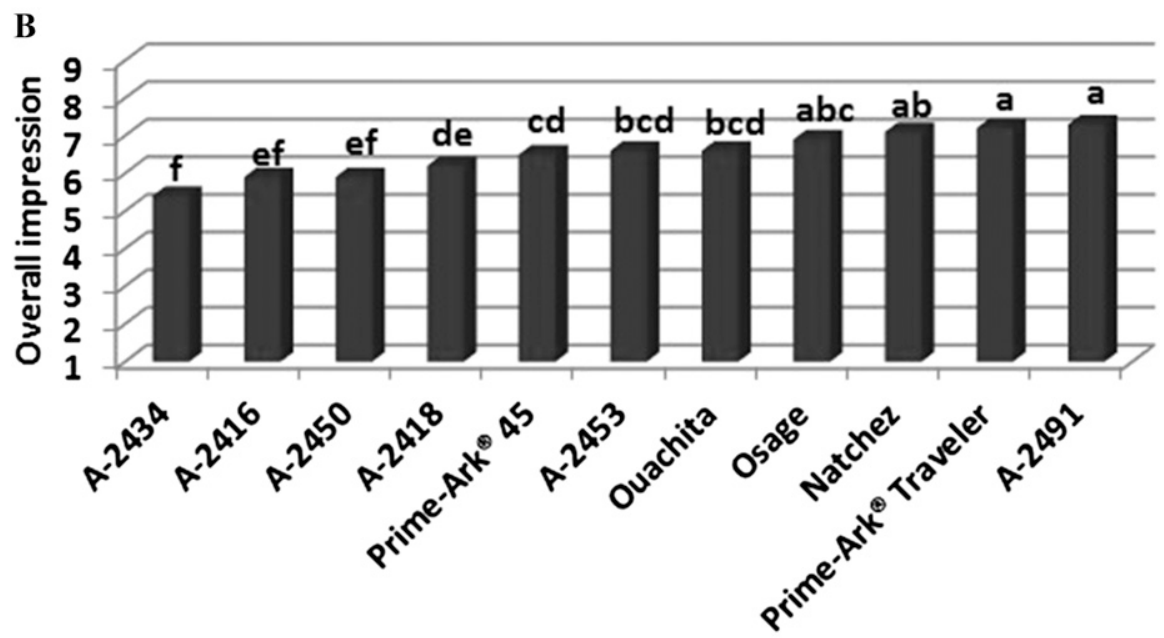

Genotypes

Fig. 3. Consumer sensory attributes for liking of (A) size and (B) overall impression for the blackberry genotypes evaluated on a 9-point hedonic scale $(1=$ dislike extremely, $5=$ neither like nor dislike, $9=$ like extremely), 2014. ${ }^{\mathrm{z}}$ Genotypes were evaluated by 74 consumer panelists. Means with different letter(s) for each attribute are significantly different $(P<0.05)$ using least significant difference.

Table 8. Drivers of liking for fresh blackberries determined by principal component regression, ${ }^{2}$ Clarksville, AR, 2014.

\begin{tabular}{|c|c|c|}
\hline Principal component & Low on dimension 1 & High on dimension 2 \\
\hline$\overline{1}$ & $\begin{array}{l}\text { Positive drivers: glossiness, loose } \\
\text { particles, overall aromatic impact, } \\
\text { blackberry aromatic, uniformity of } \\
\text { drupelets } \\
\text { Key sample: A-2491 }\end{array}$ & $\begin{array}{l}\text { Negative drivers: bitterness, } \\
\text { sourness, amount of blemishes, } \\
\text { amount of seeds, green/unripe, } \\
\text { metallic } \\
\text { Key sample: A-2434 }\end{array}$ \\
\hline 2 & Nondrivers: firmness, chemical & $\begin{array}{l}\text { Nondrivers: drupelets/berry, } \\
\text { pyrenes/berry, berry weight, } \\
\text { size of berry, moisture release }\end{array}$ \\
\hline & Key sample: A-2453 & Key sample: Natchez \\
\hline 3 & $\begin{array}{l}\text { Negative drivers: narrow berry, } \\
\text { lower intensities of sweetness, } \mathrm{pH}, \\
\text { amount of styles } \\
\text { Key samples: A-2450 }\end{array}$ & $\begin{array}{l}\text { Positive drivers: wider berry, } \\
\text { higher intensities of sweetness, } \\
\text { pH, amount of styles } \\
\text { Key samples: Ouachita and } \\
\text { Osage }\end{array}$ \\
\hline
\end{tabular}

${ }^{\mathrm{z}}$ Three principal components explaining $62.4 \%$ of variance of physiochemical and descriptive sensory data were identified using means as the data matrix. Significant effects were found for principal components 1 and $3(P=0.0003$ and 0.0130 , respectively). 
weight range of 6 to $14 \mathrm{~g}$, consumers liked midsized berries rather than large berries. Although sweetness of the blackberries was an important positive attribute, the sourness of the blackberries had more of a negative impact on the liking of the blackberries. The trained descriptive panel using references could not distinguish differences in sweetness among these genotypes, but could easily differentiate sourness. Although blackberry growers typically focus on growing sweeter berries, the perception of sweetness is actually a balance of sweetness and sourness, which should be considered when advancing breeding selections or choosing cultivars for planting. To produce commercially marketed fresh-market blackberries, there are many characteristics that are important, but our data for these genotypes suggest that a desired fresh-market blackberry should have a berry weight of 8 to $10 \mathrm{~g}$, soluble solids of $9 \%$ to $11 \%$, titratable acidity of $0.9 \%$ to $1 \%$, and a soluble solids/ titratable acid ratio of 10 to 13 . However, optimum sugar and acidity levels require more investigation as well as other important factors in flavor and aromatics. Evaluating the physiochemical and sensory attributes of fresh fruit is an important tool that can be used to determine commercial potential for selections and cultivars.

\section{Literature Cited}

ASTM International. 2009. West Conshohocken, PA.

Benvenuti, S., F. Pellati, M. Melegari, and L. Bertelli. 2004. Polyphenols, anthocyanins, ascorbic acid, and radical scavenging activity of Rubus, Ribes, and Aronia. J. Food Sci. 69:164-169.

Cavender, G., M. Liu, D. Hobbs, B. Frei, B. Strik, and Y. Zhao. 2014. Effects of different organic weed management strategies on the physiochemical, sensory, and antioxidant properties of machine-harvested blackberry fruits. J. Food Sci. 79:S2107-S2115.

Cho, M.J., L.R. Howard, R.L. Prior, and J.R. Clark. 2004. Flavonoid glycosides and antioxidant capacity of various blackberry, blueberry, and red grape genotypes determined by high-performance liquid chromatography/ mass spectrometry. J. Food Sci. and Agr. 84:1771-1782.

Clark, J.R. 2008. Primocane-fruiting blackberry breeding. HortScience 43:1637-1639.

Clark, J.R. 1999. The blackberry breeding program at the University of Arkansas: Thirty-plus years of progress and developments for the future. Acta Hort. 505:73-77.

Clark, J.R. 2005. Changing times for eastern United States blackberries. HortTechnology 15:491-494.

Clark, J.R. and C.E. Finn. 2008. New trends in blackberry breeding. Acta Hort. 777:41-47.

Clark, J.R., L.R. Howard, and S. Talcott. 2002. Antioxidant activity of blackberry genotypes. Acta Hort. 585:475-480.

Clark, J.R. and P. Perkins-Veazie. 2011. Prime$\mathrm{Ark}^{\circledR} 45$ primocane-fruiting blackberry. HortScience 46:670-673.

Clark, J.R., E.T. Stafne, H.K. Hall, and C.E. Finn. 2007. Blackberry breeding and genetics. Plant Breed. Rev. 29:19-144.

Connor, A.M., C.E. Finn, and P.A. Alspach. 2005. Genotypic and environmental variation in antioxidant activity and total phenolic content among blackberry and hybridberry cultivars. J. Amer. Soc. Hort. Sci. 130:527533.

Crisosto, H.C. and M.G. Crisosto. 2005. Relationship between ripe soluble solids concentration (RSSC) and consumer acceptance of high and low acid melting flesh peach and nectarine [Prunus persica (L.) Batsch] cultivars. Postharvest Biol. Technol. 38:239-246.

de Souza, V.R., P.A.P. Pereira, T.L.T. de Silva, L.C. de Oliveira Lima, R. Pio, and F. Queiroz. 2014. Determination of the bioactive compounds, antioxidant activity and chemical composition of Brazilian blackberry, red raspberry, strawberry, blueberry and sweet cherry fruits. Food Chem. 156:362-368.

Du, X.F., C.E. Finn, and M.C. Qian. 2010a. Volatile composition and odour-activity value of thornless 'Black Diamond' and 'Marion' blackberries. Food Chem. 119: 11127-11134.

Du, X.F., C.E. Finn, M.C. Qian, A. Kurnianta, and M. McDaniel. 2010b. Flavour profiling of 'Marion' and thornless blackberries by instrumental and sensory analysis. Food Chem. 121:1080-1088.

Finn, C.E. and J.R. Clark. 2012. Blackberry, p. 151-190. In: M.L. Badenes and D.H. Byrne (eds.). Handbook of plant breeding, Vol. 8: Fruit breeding. Springer, New York, NY.

Flora, L.F. 1979. Optimum quality parameters of muscadine grape juices, beverages, and blends. J. Food Qual. 2:219-229.

Hager, T.J., L.R. Howard, R. Liyanage, J.O. Lay, and L.R. Prior. 2008a. Ellagitannin composition of blackberry as determined by HPLC-ESI-MS and MALDI-TOF-MS. J. Agr. Food Chem. 56:661-669.

Hager, T., R. Prior, and L. Howard. 2008b. Processing and storage effects on monomeric anthocyanins, percent polymeric color, and antioxidant capacity of processed blackberry products. J. Agr. Food Chem. 56:689-695.

Hager, T., R. Prior, and L. Howard. 2010. Processing and storage effects on the ellagitannin composition of processed blackberry products. J. Agr. Food Chem. 58:11749-11754.

Hall, H.K., M.J. Stephens, C.J. Stanley, C.E. Finn, and B. Yorgey. 2002. Breeding new 'Boysen' and 'Marion' cultivars. Acta Hort. 585:91-95.

Harrison, R.E., R.M. Brennan, E.A. Hunter, S. Morel, and D.D. Muir. 1999. Genotypic, environmental and processing effects on the sensory character of Rubus and Ribes. Acta Hort. 505:25-32.

Howard, L.R. and T.J. Hager. 2007. Berry fruit phytochemicals, p. 73-104. In: Y. Zhao (ed.). Berry fruit: Value-added products for health promotion. 1st ed. CRC Press, Boca Raton, FL.

Kurnianta, A.J., C.E. Finn, and M.R. McDaniel. 2005. Descriptive sensory analysis of thornless blackberry selections to determine sensory similarity to Marion blackberry aroma and flavor. Inst. Food Technol. Ann. Mtg., New Orleans, 15-20, July (abstr.).

Kurnianta, A.J. 2005. Descriptive sensory analysis of thornless blackberry selections to determine sensory similarity to 'Marion' blackberry flavor. Ore. State Univ., Corvallis, Master's thesis.

Lewers, K.S., S.Y. Wang, and B.T. Vinyard. 2010. Evaluation of blackberry cultivars and breeding selections for fruit quality traits and flowering and fruiting dates. Crop Sci. 50: 2475-2491.
Manganaris, G.A., V. Goulas, A.R. Vicente, and L.A. Terry. 2014. Berry antioxidants: Small fruits providing large benefits. J. Sci. Food Agr. 94:825-833.

Moore, J.N., G.R. Brown, and E.D. Brown. 1974. Relationships between fruit size and seed number and size in blackberries. Fruit Var. J. 28:40-50.

Moore, J.N., C. Lundergan, and E.D. Brown. 1975. Inheritance of seed size in blackberry. J. Amer. Soc. Hort. Sci. 100:377-379.

Moyer, R.A., K.E. Hummer, C.E. Finn, B. Frei, and R.E. Wrolstad. 2002. Anthocyanins, phenolics, and antioxidant capacity in diverse small fruits: Vaccinium, Rubus and Ribes. J. Agr. Food Chem. 50:519-525.

Ness, A.R. and J.W. Poulens. 1997. Fruit and vegetables, and cardiovascular disease: A review. Intl. J. Epidemiol. 26:1-13.

Prior, R., G. Cao, A. Martin, E. Sofic, J. McEwen, C. O'Brien, and C.M. Mainland. 1998. Antioxidant capacity as influenced by total phenolic and anthocyanin content, maturity, and variety of Vaccinium species. J. Agr. Food Chem. 46:2686-2693.

Radočaj, O., V. Vujasinovic, E. Dimić, and Z. Basić. 2014. Blackberry (Rubus fruticosus L.) and raspberry (Rubus idaeus L.) seed oils extracted from dried press pomace after longterm frozen storage of berries can be used as functional food ingredients. Eur. J. Lipid Sci. Technol. 116:1015-1024.

Sariburun, E., S. Şahin, C. Demir, C. Türkben, and V. Uylaşer. 2010. Phenolic content and antioxidant activity of raspberry and blackberry cultivars. J. Food Sci. 75:328-335.

Seeram, N.P. 2008. Berry fruits: Compositional elements, biochemical activities, and the impact of their intake on human health, performance, and disease. J. Agr. Food Chem. 56:627-629.

Sellappan, S., C.C. Akoh, and G. Krewer. 2002. Phenolic compounds and antioxidant capacity of Georgia-grown blueberries and blackberries. J. Agr. Food Chem. 50:2432-2438.

Siriwoharn, T., R.E. Wrolstad, C.E. Finn, and C.B. Pereira. 2004. Influence of cultivar, maturity, and sampling on blackberry [Rubus L. hybrids] anthocyanins, polyphenolics, and antioxidant properties. J. Agr. Food Chem. 52:8021-8030.

Slinkard, K. and V.L. Singleton. 1977. Total phenol analysis: Automation and comparison with manual methods. Amer. J. Enol. Viticult. 28:49-55

Soares, S., S. Kohl, S. Thalmann, N. Mateus, W. Meyerhof, and V. Freitas. 2013. Different phenolic compounds activate distinct bitter taste receptors. J. Agr. Food Chem. 61:15251533.

Steinmetz, K.A. and J.D. Potter. 1996. Vegetables, fruit, and cancer prevention: A review. J. Amer. Diet. Assoc. 96:1027-1039.

Strik, B.C., J.R. Clark, C.E. Finn, and M.P. Bañados. 2007. Worldwide blackberry production. HortTechnology 17:205-213.

Takeda, F. 1993. Characterization of blackberry pyrenes. HortScience 28:488 (abstr.).

Tomás-Barberán, F.A. and J.C. Espín. 2001. Phenolic compounds and related enzymes as determinants of quality in fruits and vegetables. J. Food Sci. Agr. 81:853-876.

Tomlik-Wyremblewska, A., J. Zieliński, and M. Guzicka. 2010. Morphology and anatomy of blackberry pyrenes (Rubus L., Rosaceae) elementary studies of the European representatives of the genus Rubus L. Flora 205:370-375. 
U.S. Department of Agriculture (USDA). 2014. National Agricultural Statistics Service, Blackberry Statistics. 4 Feb. 2016. <http://www.nass. usda.gov/Statistics_by_Subject/?sector=CROPS $>$.

Wada, S. and B.M. Reed. 2010. Seed coat morphology differentiates blackberry cultivars. J. Amer. Pomol. Soc. 64:152-161.

Wada, S., H. Nonogaki, and B.M. Reed. 2010. Identifying blackberry cultivars by seed structure. Oregon State University Extension Service Publication. EM9002.

Walker, T.L., J.R. Morris, R.T. Threlfall, G.L. Main, O. Lamikanra, and S. Leong. 2001. Density separation, storage, shelf life and sensory evaluation of 'Fry' muscadine grapes. HortScience 36:941-945.

Wang, Y., C. Finn, and M.C. Qian. 2005. Impact of growing environment on Chickasaw blackberry (Rubus L.) aroma evaluated by gas chromatography olfactometry dilution analysis. J. Agr. Food Chem. 53:35633571.

Wang, W.D., S.Y. Xu, and M.K. Jin. 2009. Effects of different maceration enzymes on yield, clarity and anthocyanin and other polyphenol contents in blackberry juice. Int. J. Food Sci. Technol. 44:2342-2349. 